\title{
REAL ESTATE VALUATION, CURRENT ACCOUNT AND CREDIT GROWTH PATTERNS, BEFORE AND AFTER THE 2008-9 CRISIS
}

\author{
Joshua Aizenman \\ Yothin Jinjarak \\ Working Paper 19190 \\ http://www.nber.org/papers/w19190
NATIONAL BUREAU OF ECONOMIC RESEARCH
1050 Massachusetts Avenue
Cambridge, MA 02138
June 2013

The views expressed herein are those of the authors and do not necessarily reflect the views of the National Bureau of Economic Research. We thank Livio Stracca and the participants at the conference on "Current Account Imbalances and International Financial Integration," hosted by the European Commission in Brussels, 6-7 December 2013, as well as the seminar at Victoria University of Wellington, for useful comments and suggestions.

NBER working papers are circulated for discussion and comment purposes. They have not been peerreviewed or been subject to the review by the NBER Board of Directors that accompanies official NBER publications.

(C) 2013 by Joshua Aizenman and Yothin Jinjarak. All rights reserved. Short sections of text, not to exceed two paragraphs, may be quoted without explicit permission provided that full credit, including (c) notice, is given to the source. 
Real Estate Valuation, Current Account and Credit Growth Patterns, Before and After the 2008-9 Crisis

Joshua Aizenman and Yothin Jinjarak

NBER Working Paper No. 19190

June 2013, Revised March 2014

JEL No. F15,F21,F32,R21,R31

\begin{abstract}
$\underline{\text { ABSTRACT }}$
We explore the stability of the conditioning variables accounting for the real estate valuation before and after the crisis of 2008-9, in a panel of 36 countries, recognizing the crisis break. We validate the robustness of the association between the real estate valuation and lagged current account patterns, both before and after the crisis. The most economically significant variable in accounting for real estate valuation changes turned out to be the lagged real estate valuation appreciation (real estate inflation minus CPI inflation), followed by lagged declines of the current account/GDP, lagged domestic credit/GDP growth, and lagged equity market valuation appreciation (equity market appreciation minus CPI inflation). A one standard deviation increase in lagged real estate appreciation is associated with a $10 \%$ increase in the present real estate appreciation, larger than the impact of a one standard deviation deterioration in the lagged current account/GDP (5\%) and of the lagged domestic credit/GDP growth (3\%). The results are supportive of both current account and credit growth channels, with the momentum channels playing the most important role. Smaller current account/GDP surpluses or larger deficits may serve as warning signals, especially when coinciding with credit expansion and real estate appreciation during the past several quarters.
\end{abstract}

Joshua Aizenman

Economics and SIR

USC

University Park

Los Angeles, CA 90089-0043

and NBER

aizenman@usc.edu

Yothin Jinjarak

DeFiMS SOAS

University of London, United Kingdom

and ADB Institute, Japan

yj5@soas.ac.uk 


\section{Introduction and overview}

The global crisis of 2008-9 sparked a vibrant debate on the factors contributing to the crisis. Were global imbalances or excessive credit growth the key suspects? Contributors to the debate include Borio and Disyatat (2011), conjecturing that the main causing factor to the financial crisis was not "excess saving" but the "excess elasticity" of the international monetary and financial system; and Obstfeld (2012:20), noting that "The balance sheet mismatches of leveraged entities provide the most direct indicators of potential instability, much more so than do global imbalances, though the imbalances may well be a symptom that deeper financial threats are gathering." Against this background, we revisit these questions in the context of the real estate market. The macro importance of the real estate market is well appreciated by now. A prime example of it has been the U.S., where Leamer (2007)'s title succinctly summarized it: "Housing is the business cycle."

A priori, one expects that both the current account and credit growth trends would impact the valuation of national real estates. A primary link between real estate valuation and the current account deficit follows from national accounting and the absorption approach. Growing current account deficits is a signal of a growing gap between the spending of domestic residents [absorption] and their output. As long as the demand for key non-traded durable assets, like real estate, is positively correlated with absorption, one expects higher current account deficits to be associated with higher real estate valuation. Yet, as most households co-finance the purchase of their dwelling through the banking system, greater financial depth and accelerated growth rate of credit tend to increase the demand for houses, probably increasing the real estate valuation.

Thus, one expects that both current account and credit trends matter for the valuation of real estate, and a priori there is no obvious reason to surmise which of the two should dominate. In Aizenman and Jinjarak (2009) we looked empirically at these issues in 41 countries, for the years 1990-2005, investigating the association between lagged current account deteriorations and the appreciation of the real estate prices/GDP deflator, controlling for macro factors associated with real estate valuation [lagged GDP/capita growth, inflation, financial depth, institution, urban population growth and the real interest rate]. We found a strong positive association between lagged current account deteriorations and an appreciation of the real estate, where the real appreciation is magnified by financial depth, and mitigated by the quality of 
institutions. Intriguingly, the economic importance of current account variations, in accounting for the real estate valuation, exceeds that of the other variables, including the real interest rate and inflation.

A growing literature identified several related channels contributing to the positive association of the current account and credit growth patterns with real estate valuation. Tomura (2010) analyzed the roles of credit market conditions in the endogenous formation of housingmarket boom-bust cycles, in a business cycle model. When households are uncertain about the duration of a temporary high income growth period, expected future house prices rise during a high growth period and fall at the end of the period. These developments induce in his model expectation-driven boom-bust cycles in house prices, only if the economy is open to international capital flows. Furthermore, high maximum loan-to-value ratios for residential mortgages per se do not cause boom-bust cycles without international capital flows. Laibson and Mollerstrom (2010) noted that national asset bubbles may explain the international imbalances -- the bubbles raised consumption, resulting in large trade deficits. In their sample of 18 OECD countries plus China, movements in home prices alone explain half of the variation in trade deficits. Gete's (2010) model showed that an increased demand for housing may generate trade deficits without the need for wealth effects or trade in capital goods, and that housing booms are larger if the country can run a trade deficit. These predictions were found consistent with the pre-crisis experience of the OECD countries. Adam et al. (2011) outlined an open economy asset pricing model with households characterized by subjective beliefs about price behavior and update these beliefs using Bayes' rule. They show that the resulting belief dynamics propagate considerable economic shocks and contribute to replicating the empirical evidence of the association between current account patterns and real estate valuations. Belief dynamics can temporarily delink house prices from fundamentals, so that low interest rates can fuel a house price boom.

As there is no reason for the relative importance of the current account and the credit patterns to stay stable overtime in accounting real estate valuation, we explore in this paper the degree to which the pre global crisis patterns continues to hold after the crisis. Specifically, we look at the following questions: 
i. Stability of the key conditioning variables accounting for the real estate valuation before and after the crisis; specifically the relative importance of the current account and credit growth patterns.

ii. The importance of 'momentum' in the pricing of real estate, as measured by the impact of lagged real estate appreciation in accounting for the present real estate appreciation, controlling for other macro factors. This issue is related to concerns about possible bubble dynamics, where lagged appreciation is reinforcing expectations of future appreciation.

iii. Symmetry of the patterns during real estate appreciation versus real estate depreciation.

iv. The possible two way causality between current account and real estate valuation patterns.

v. The degree to which the valuation of equities is accented by similar conditioning variables.

Overall, our paper reveals a complex of time varying patterns, yet it validates the robustness of the association between real estate valuation of lagged current account patterns both before and after the crisis. The base regression is a dynamic panel estimate of 36 countries, during the periods 2005:I -2012:IV, recognizing the crisis break. It accounts for the appreciation rate of the real estate valuation (real estate inflation minus CPI inflation) as explained by the following correlates: lagged appreciation rate of the real estate valuation, lagged decline in the current account/GDP, lagged changes in the domestic credit/GDP, lagged changes in the equity market valuation appreciation (equity market appreciation minus CPI inflation), and a vector of lagged changes of macro controls [inflation, growth of industrial production, TED spreads, sovereign spreads, VIX, and international reserves]. The most economically significant variable in accounting for real estate valuation changes turned out to be the lagged real estate valuation appreciation, followed by lagged declines of the current account/GDP, lagged domestic credit/GDP growth, and lagged equity market valuation appreciation. The first three effects are economically substantial: a one standard deviation increase in lagged real estate appreciation is associated with a $10 \%$ increase in the present real estate appreciation, much larger than the impact of a one standard deviation decline in the lagged current account (5\%), and that of lagged increase in the domestic credit/GDP growth (3\%). Thus, the results are supportive of both current 
account and credit growth channels, with the animal-spirits and expectations channels playing the most important role in the boom and bust of real estate valuation.

While positive reverse feedback of real estate appreciation to current account deteriorations cannot be ruled out theoretically, we find that it is not supported during our sample period. We find support for a positive feedback of real estate appreciation to equity market appreciation, which is consistent with the wealth effects from real estate valuation to equity investment.

\section{Sample}

We use quarterly data to understand how short- to medium-term adjustment of the real estate valuation interacts with current accounts, domestic credit, and relevant macro and global variables. Using quarterly data comes at a cost of sample length: subject to data availability, our data covers the period of 2005:I to 2012:IV. Obviously we miss out earlier episodes of real estate booms and busts. However, in the present context of our investigation this may not be so costly since previous cycles would be varying across countries, meaning that there would be a variety of other driving factors in country-specific episodes. On the other hand, the current sample period fits well with our interests that specifically focus on the real estate valuation over the global crisis, with quarterly adjustment dynamics. Alternatively, using annual data instead would allow for a longer sample period back in the historical past, but could not capture the dynamics of short- to medium-term interactions between real estate data and confounding macro fundamentals that we try to understand.

The data are drawn from several sources, as shown in Appendix A, including Oxford Economics, Economist Intelligence Unit (EIU), Federal Reserve Economic Data (FRED), and Credit Market Analysis (CMA). Our main variable of interests is real estate valuation appreciation (real estate inflation minus CPI inflation). As a user of secondary data, we are made well aware that the primary collection method of our most important variable, the real estate valuation series, is known to be highly heterogeneous across countries. National statistical offices and local real estate agencies have their own approaches in compiling the data; e.g. some are repeated sales, others are not; some include both residential and commercial, others do not, etc. Hence, pooling real estate series across countries amounts to an aggregation problem. Our 
real estate series, which are drawn from a compilation of Oxford Economics database, are also subject to this data issue, as is the case in other earlier studies and datasets. ${ }^{1}$ Yet, as is shown in Aizenman and Jinjarak (2009) using real estate data from different cross-country databases, residential series and commercial real estate series, the econometric evidence are largely consistent across the data sets on the empirical relationships of real estate, current account, and macro variables.

Altogether there are 36 countries in the sample, covering both developed and emerging markets. Appendix A provides the list of countries and Appendix B shows geographically the locality of real estate markets included. Some of these are large, hot spot markets, widely monitored and publicized by the press, e.g. China and the US, whereas many others are smaller in size and may not be known as boom-bust spots in the global real estate markets. As shown by standard deviation of real estate valuation appreciation highlighted in the figure of Appendix B, several of these countries are considered highly volatile markets for the period before and after the global crisis.

\subsection{Preliminary statistics}

Panel unit root tests suggest that real estate valuation appreciation, current account/GDP deterioration, and domestic credit growth/GDP are all nonstationary. As the power of unit root tests undoubtedly varies across study samples, not to mention panel data extension of the tests, we report both Im-Pesaran-Shin statistic and Levin-Lin statistic (Appendix C). These two tests assume that all series are non-stationary under the null hypothesis; the former is consistent under the alternative that only a fraction of the series are stationary, while the latter assumes that all series are stationary under the alternative. Both tests appear consistent with each other in our sample, pointing to the existence of unit roots in the series. Next, we examine whether there is any co-integrating relationship among these variables. ${ }^{2}$

\footnotetext{
${ }^{1}$ The cross-country series currently available are not sufficiently detailed to resolve the issues, as well as in term of cross-series comparability, in contrast to, for example, Standard and Poor's (S\&P) Case-Shiller for the US real estate series.

${ }^{2}$ To smooth seasonal fluctuations in quarterly real estate valuation appreciation, current account/GDP deterioration, and domestic credit growth/GDP, we use their four-quarter moving averages (current plus three lags) here and in the following estimation.
} 
The panel co-integration test does not reject the null of no co-integration between real estate valuation appreciation and current account/GDP deterioration; real estate valuation appreciation and domestic credit growth/GDP; real estate valuation appreciation and equity market valuation appreciation (equity market appreciation minus CPI inflation); current account /GDP deterioration and domestic credit growth/GDP. The panel co-integration test statistics have the null of no integration for all cross-sections of countries, based on Westerlund panel error-correction-model (ECM) tests. We report test statistics both when an alternative is error correction term less than zero for at least one country, and when an alternative is error correction term less than zero for all countries. Both statistics are consistent with each other in rejecting cointegration. While there is some weak evidence of co-integration between current account/GDP deterioration and domestic credit growth/GDP, this is not statistically significant at the 5 percent level of the test.

Based on the panel unit-root and panel co-integration tests, the application of dynamic panel data estimation in first-differenced series is deemed necessary for the real estate and macro variables in our sample. With 36 countries and over 20 quarterly periods for each country, the fixed-effect estimation may also be applicable. However, given that several series are known to be highly persistent in the panel of countries (i.e. real estate prices, current accounts, domestic credit growth, as well as equity prices), including lagged terms of dependent variables on the right-hand side of estimating equations may entail empirical correlation between the lagged regressors and the error terms, and hence the endogeneity issue. For these reasons, we focus in the following on coefficient estimates from dynamic panel estimation as our main econometric evidence.

\subsection{Patterns of real estate valuation appreciation and current account/GDP deterioration}

Mean reversion in real estate appreciation across national markets is quite noticeable in the data. As shown in Figure 1, we plot cumulative real estate valuation appreciation for the period of 2005:I-2007:III on the horizontal axis, and cumulative real estate valuation appreciation for the period of 2008:III-2012:IV on the vertical axis. The relationship between cumulative real estate appreciation between the two periods is negative: the slope coefficient from OLS estimation is -0.5 and is statistically significant at the 1 percent level, with $\mathrm{R}^{2}=0.28$. Ireland, Spain, South Africa, United States, and United Kingdom provide clear example of mean 
revision before and after the global crisis. There are a few outliers in this relationship; including mostly small markets, i.e. Hong Kong, Ireland, and Romania (not included in the plot for illustrative purposes).

Once we plot the country-specific evolution of real estate valuation appreciation series, it appears that there are large differences across countries in the associated patterns against the backdrop of the global financial crisis. Shown in Figure 2A, real estate valuation varied markedly before and after the global crisis events, as marked by the two vertical lines for 2007:III (Northern Rock event) and for 2008:III (Lehman Brother event), respectively. While real estate valuation appreciation of some countries increased until the crisis events (e.g. Canada, Ireland), for several others the real estate valuation appreciation valuation were already spiraling downward even before the global crisis (e.g. US, South Africa). For some markets, the real estate valuation appreciation appear to bounce back soon after the global financial panic (e.g. Australia), while for a few others, national real estate markets continued to be highly volatile (e.g. Hong Kong, Singapore).

The patterns of current account/GDP deterioration and domestic credit growth/GDP were also heterogeneous across countries over the periods before and after the global financial crisis. As shown in Figure 2A for current account/GDP deterioration and in Figure 2B for domestic credit growth/GDP, the quarterly adjustment dynamics of these two variables tracked real estate valuation appreciation in some countries quite well, whereas for several others there appeared no relationship between the two variables and the real estate valuation appreciation valuation.

Hence, as an alternative to using the global crisis events (i.e. Northern Rock even and Lehman Brothers event) to mark the turning points, we assign a new binary variable "Current account/GDP's deterioration Break" to identify a country-specific break date, or structural shift, in the empirical association between real estate valuation appreciation and current account/GDP deterioration, according to QLR statistics ${ }^{3}$; and a new binary variable "Domestic credit/GDP's Break", which is defined similarly for the stock of domestic credit/GDP. As shown in figures 2A

\footnotetext{
${ }^{3}$ Quandt likelihood ratio test for a break at an unknown break date (Stock and Watson, 2012). Here we are mainly interested in empirical breaks of the association between real estate valuation appreciation and current account/GDP deterioration (or growth of domestic credit/GDP) in each country over the sample period of 2005:I-2012:IV. For identification of extreme capital flow episodes from 1986-2009, see Forbes and Warnock (2012).
} 
and $2 \mathrm{~B}$, these empirical turning points closely resemble the global crisis events for a majority of countries (notably, i.e. US, UK, Australia, Spain), whereas they were not the same turning points in a number of countries.

\section{Baseline Results}

\subsection{The Global Financial Crisis}

From our baseline estimation, real estate valuation is positively and significantly associated with current account deficits in both periods before and after the crisis of 2008-09. Real estate valuation is positively associated with domestic credit growth to a lesser degree, statistically significant only in the period before the crisis [see Appendix D for the empirical specification]. Column 1 of Table 1 provides the main results, using 2007:III (Northern Rock event) as the turning point that marked the global financial crisis, while column 2 uses 2008:III (Lehman Brothers event) as an alternative turning point. Both estimation results are consistent with each other, suggesting that the association of real estate valuation appreciation with current account/GDP deterioration and with domestic credit growth/GDP are positive and statistically significant (accounting coefficient estimates on the four lags of current account deficit and domestic credit growth). ${ }^{4}$

The baseline results also show that equity market appreciation and inflation are empirically associated with real estate valuation, while the relationship with other variables (growth, global interest rate, sovereign risk, reserve accumulation) is not supported in the current sample. The positive association between real estate valuation appreciation and equity market valuation appreciation is consistent with the wealth effects from real estate valuation to equity investment, as capital gains in the equity investment spillover to the real estate sector. The association between real estate valuation appreciation and inflation is negative as one might expect. The coefficients of other variables are not statistically significant; for some variables, coefficient estimates have an unexpected sign (i.e. growth of industrial production, TED spread, and foreign reserve accumulation).

\footnotetext{
${ }^{4}$ The coefficients are obtained from the Arellano-Bond dynamic panel estimation. While only lagged real estate valuation appreciation is treated as an endogenous regressor, the autocorrelation test suggests that $A R(2)$ is only marginally significant at the 10 percent level, but not at the 5 percent level.
} 
Interestingly, coefficient estimates of lagged real estate valuation appreciation indicate persistence in real estate valuation up to two quarters, consistent with popular commentaries that real estate markets are driven by animal spirits and momentum, with macroeconomic and regulatory environment playing a supporting role. The lagged real estate coefficients are equal to 0.6 for the first two quarters and statistically significant at the 1 percent level, suggesting that more than half of real estate valuation was carried on from one quarter to the next three quarters on average. ${ }^{5}$ However, our sample focuses on a specific episode before and after the global crisis. Hence, the findings do not imply that expectation-driven persistence in real estate valuation may last only half a year, but instead that this observed momentum appears to be the case over the period of 2005:I to 2012:IV.

\subsection{Breaks in current account deficits and domestic credit growth}

The positive association between real estate appreciation and current account deterioration remains robust for alternative turning points in their relationship, but the association between real estate appreciation and domestic credit growth does not. As shown earlier in Figures 2A and 2B, for a majority of countries, the global crisis events (Northern Rock in 2007:III and Lehman Brothers in 2008:III) coincided with the empirical turning points in the relationship between real estate valuation appreciation and current account/GDP deterioration, as well as the relationship between real estate valuation appreciation and domestic credit growth/GDP. To verify, instead of using a Global crisis binary variable as done in Table 1, we use in Table 2 a new binary variable "Current account/GDP deterioration's Break" that identifies a country-specific turning point in the association between real estate appreciation and current account/GDP deterioration, according to QLR statistics as described in Section 2.2; "Growth of domestic credit/GDP's Break" is defined similarly for domestic credit growth/GDP; both are depicted in Figure 2. These country-specific breaks enter the estimation of Table 2 individually, and also as interaction terms with current account deficit/GDP series and with growth of domestic credit/GDP series. Table 2 column 1 reports the dynamic panel estimates from these new specifications. We find that the positive association between real estate valuation appreciation and current account/GDP deterioration is still statistically significant, while the

\footnotetext{
${ }^{5}$ The coefficient estimate on a third lag is negative, but much smaller than the first two, so the net effect remains positive for three quarters. In Section 4, we revisit the economic significance of lagged real estate valuation in more details.
} 
positive association between real estate valuation appreciation and growth of domestic credit/GDP becomes insignificant.

In addition, with these alternative turning points, using the fixed-effect estimation does not change the main finding on the positive and statistically significant association between real estate valuation and current account deficit. As shown in column 2 of Table 2, the coefficient estimates of current account/GDP deterioration remain statistically significant in the fixed-effect estimation; the coefficient estimates of lagged real estate valuation appreciation and equity market valuation appreciation also remain statistically significant. Further, current account deficit/GDP enters the estimation positive and statistically significant both individually and as interaction terms. The explanatory power, as measured by $\mathrm{R}^{2}$ in column 2 , suggests that the estimation is able to explain about 80 percent of variation in the real estate valuation over the period of 2005:I to 2012:IV. Since a drawback of fixed-effect estimation is a lack of empirical treatment on endogeneity in the presence of lagged dependent variable (real estate valuation appreciation), we take the fixed-effect estimates as supportive evidence and continue onwards with the dynamic panel estimation in the following. ${ }^{6}$

\subsection{Current account deterioration vis-à-vis of domestic credit growth}

Horseracing lagged current account/GDP changes vis-à-vis lagged growth of domestic credit/GDP suggests that the former is more statistically significant in the empirical association with real estate valuation changes. The findings in Tables 1 and 2 indicates that the positive association between real estate valuation appreciation and lagged current account/GDP declines is always statistically significant, whereas the association between real estate valuation appreciation and lagged growth of domestic credit/GDP is insignificant in several specifications (i.e. columns 1 and 2 of Table 2). Perhaps this difference might be due to common underlying

\footnotetext{
${ }^{6}$ For real estate valuation and current account relationship, it is beyond a scope of the study to defend either method of the panel estimation. Hypothetically, in the context of reduced-form analysis, endogenous regressors may include not only lagged real estate valuation appreciation, but also additional lags of the right-hand-side variables, i.e. current account/GDP deterioration, growth of domestic credit/GDP, and equity market valuation appreciation. Alternatively, one may consider current account as endogenous and study the present value of current account with real estate valuation (and for that matter, other asset prices) and VAR (although the causal ordering has never been clear in such setting for all contemporaneous coordinates). Essentially, in the general-equilibrium analysis, all the variables would be endogenous, even the incidence of global crises. Hence, since we take no stance and there is no point to be too defensive about the main specifications reported in this paper, instead we hereby provide a battery of results based on various specifications for the readers to judge.
} 
factors in both current account and credit growth series; the patterns illustrated in Figures 2A and 2B seem to suggest that both series tracked real estate valuation appreciation quite well for a majority of countries, before and after the global crisis. Alternatively, the difference might be due to insufficient lagged adjustment allowed for these two variables in the estimation. Accordingly, in Table 3 we allow for four lags of current account/GDP deterioration in column 1 , excluding growth of domestic credit/GDP and a binary variable for global crisis or a binary variable for turning points in the association between real estate valuation appreciation and current account/GDP deterioration. Similarly, we allow for four lags of growth of domestic credit/GDP in column 2, excluding current account /GDP declines and a binary variable for global crisis or for the turning points in growth of domestic credit/GDP. Based on these alternative specifications, the findings are consistent with the coefficient estimates of Tables 1 and 2. Without growth of domestic credit/GDP in the estimation, the association between real estate valuation appreciation and current account/GDP deterioration remains positive and significant (column 1). On the other hand, without current account/GDP deterioration in the estimation, the association between real estate valuation appreciation and growth of domestic credit/GDP is still weak and insignificant at all lags (column 2).

Based on statistical pair-wise correlation and panel co-integration tests, multi-collinearity between current account deterioration and growth of domestic credit is unlikely, at least for the 2005:I-2012:IV sample. As discussed earlier via Appendix C, the panel co-integration tests cannot reject the null of no co-integration between current account/GDP declines and growth of domestic credit/GDP. We also find that the pair-wise correlation between the two series is only 0.1 across countries in our sample. Nevertheless, this does not imply that we should rule out altogether potential feedback between current account deficit changes and growth of domestic credit in other samples, presumably with a longer sample and covering episodes other than we currently examine. Useful extension may also try to understand causality between current account changes and credit growth across time and countries. One may suspect some intertwining of household debt accumulation, consumption of durables, and domestic indebtedness in foreign currency become important factors in such setting. 


\section{Sensitivity Analysis}

\subsection{Reverse feedback}

We find that reverse and positive feedback of real estate appreciation to current account deterioration is not supported by the data over the crisis period. To investigate for possible feedback from real estate valuation appreciation, Table 4 column 1 reverses the empirical specification of column 1 in Table 1 by placing current account/GDP declines on the left-hand side of the estimating equation. This specification is not a straightjacket model of current account, but is a simple verification of possible influence on current account from real estate valuation. The coefficient estimates suggest that there is no evidence of positive feedback of real estate valuation appreciation to current account/GDP declines in the data. As shown in Table 4, the coefficient estimates of real estate valuation appreciation, while statistically significant, have negative sign, opposite to what one might expect, before and after the global crisis period. This counterintuitive finding seems to be rather consistent with the panel co-integration tests in Appendix $\mathrm{C}$ where we cannot reject the null of no co-integration between current account/GDP deterioration and real estate valuation appreciation. However, these non-findings do not rule out positive and reverse feedback of real estate appreciation to current account deteriorations in other samples, but only that any support for such reverse feedback is not prevalent during 2005:I2012:IV period that we study.

On the other hand, and contrary to panel co-integration tests, the coefficient estimates of dynamic panel estimation suggest positive feedback of real estate appreciation to equity market appreciation, a finding consistent with the wealth effects from real estate valuation to equity investment. In column 2 of Table 4, we replace a left-hand-side variable of the estimating equation with equity market valuation appreciation. As shown in the column, a positive association between equity market valuation appreciation and real estate valuation appreciation is statistically significant before and after the global crisis period. However, we suspect that common underlying causes of these two variables may not be the same. In the present context, the association between equity market valuation appreciation and current account/GDP deterioration is negative before the global financial crisis (Table 4 column 2), whereas the association is positive between real estate valuation appreciation and current account/GDP declines (earlier in Table 1 column 1). Interestingly, the relationship between equity market 
valuation appreciation and growth of industrial production, TED spread, sovereign CDS, and foreign reserve accumulation in Table 4 are also statistically significant with expected signs, in contrast to the equation of real estate valuation in Table 1. This finding may also imply that the momentum and animal-spirits channels in the real estate valuation can change rather independently from those in equity investment over the crisis period. ${ }^{7}$

\subsection{Asymmetric adjustment}

Additional sensitivity checks show that for appreciation episode of the real estate valuation, a positive association between real estate appreciation and current account deterioration is statistically significant, while the positive association between real estate appreciation and growth of domestic credit is statistically significant but to a lesser degree. In Table 5, we allow for asymmetric adjustment, assigning different coefficients for the estimation of real estate valuation appreciation (column 1) and the estimation of real estate valuation depreciation (column 2); the specification is closely resembled to that in Table 1, but here we separate the whole sample into real estate appreciation sample and real estate depreciation sample. For the real estate appreciation episode, estimation results are largely consistent with the results from the whole-sample estimation in column 1 of Table 1; an exception is coefficient estimates of equity market valuation appreciation and inflation are insignificant. For the real estate depreciation episode, the estimation results are markedly different from the whole-sample estimation, as only lagged real estate valuation appreciation and equity market valuation appreciation are found statistically significant in the association with the real estate valuation. Hence, we find that when real estate markets were on the rise, the real estate valuation adjusts with respect to macro variables differently from when the markets were declining. Asymmetric bubbly dynamics are evident in the real estate valuation.

\subsection{Additional Results}

To explore alternative hypotheses and specifications, we provide additional results in Table 7. First, we estimated two new regressions, one replacing the current account deficit with gross inflows, and another replacing the current account deficit with gross inflows plus gross

\footnotetext{
${ }^{7}$ Carroll, Otsuka, and Slacalek (2011) find that an eventual marginal propensity to consume from a $\$ 1$ change in housing wealth is about 9 cents, substantially larger than the effect of shocks to financial wealth. Hence, our emphasis placed on the real estate valuation has additional merit at a macro level.
} 
outflows, based on the data from IMF Balance of Payments Statistics. The results, reported in columns (1) and (2) of Table 7, suggest that the association between the gross flows and real estate valuation appreciation is not as strong as the association between the current account deficit and real estate valuation appreciation. We also consider the composition of capital flows, focusing the debt inflows, net flows, and inflows plus outflows in columns (3), (4), and (5), respectively. The results suggest that these disaggregated flows are not statistically associated with the real estate valuation appreciation. One limitation of using the gross flows and debt flows is that the quarterly data of these flows are only available for a subset of countries; in the present estimation, using the series reduced our sample by half.

Second, we added two new regressions, one for countries faced with banking crisis during the sample period, and another for countries without the banking crisis, based on the identification of Laeven and Valencia (2012). ${ }^{8}$ The results, shown in columns (6) and (7) of Table 7, suggest that the domestic credit growth is more statistically significant in the banking crisis group, while both the current account and the credit growth are significant in the non crisis group. Third, we added two new regressions, one for countries with high level of financial openness, and another for countries with low level of financial openness. The level of financial openness is derived from Chinn and Ito (2013) de jure measure of financial openness. Countries with the index above the 2004 global average of financial openness as of the first quarter of 2005 (beginning of the sample) are considered having high level of financial openness; the other countries are considered having low level of financial openness. ${ }^{9}$ The results, reported in columns (8) and (9) of Table 7, suggest that while the positive association between current account deterioration and real estate valuation appreciation holds for both high financial openness group and low financial openness group, the coefficients are more statistically significant for the latter.

Fourth, we added two new regressions for Euro area countries and non-Euro countries in columns (10) and (11) of Table 7, respectively. The results suggest that the relationship between real estate valuation with the current account and the credit growth are more statistically

\footnotetext{
${ }^{8}$ This group of countries includes Austria, Belgium, Switzerland, Germany, Denmark, Spain, France, United Kingdom, Greece, Hungary, Ireland, Italy, Netherlands, Portugal, Sweden, and United States. These countries are identified as facing the banking crisis in 2008:Q3, except United States, in 2007:Q4.

${ }^{9}$ High financial openness group includes: AT, AU, BE, CA, CH, CZ, DE, DK, ES, FI, FR, GB, GR, HK, HU, ID, IE, IT, JP, NL, NO, NZ, PT, RO, SE, SG, TW, and US.
} 
significant in the non-Euro group. Potentially the asset bubbles may be driven by the Tri-lemma consideration, and this linkage should be taken into account more rigorously in a longer period and larger set of countries. We also added two additional regressions for OECD and non-OECD countries, shown in columns (12) and (13) of Table 7; the results suggest that the credit growth is more statistically significant in the former, whereas the current account change is more statistically significant in the latter. Hence, it seems that there is some heterogeneity in the factors driving real estate valuation between these groups of countries. Lastly, we added a regression using a new control based on estimates of mortgage origination in USA as measure that may help capture the common shock driving real estate markets across countries. The result, reported in column (14) of Table 7, suggests that this variable cannot sufficiently explain the variation in real estate valuation across countries. Nevertheless, the underlying common causes, interdependence of real estate bubbles across countries, as well as volume, building consents, and construction cycles, warrant further investigation in the future extensions.

\subsection{Economic Significance}

Based on sample standard deviation and estimation results, the economic significance on real estate valuation is driven mostly by lagged real estate appreciation, followed by current account deterioration, growth of domestic credit, and equity market appreciation. We reach this conclusion by accounting for all our main findings and sensitivity checks, including in particular positive feedback of real estate appreciation to equity market appreciation (Table 4) and asymmetric adjustment in real estate appreciation and in depreciation episodes (Table 5). Essentially, we revise the empirical specification of column 1 in Table 1, hereby verifying our estimation in Table 6 by treating real estate appreciation and equity market appreciation both as endogenous regressors. Our benchmark findings are reported in Table 6, for the whole sample in column 1, and for the episode of real estate appreciation in column 2. Next, we calculate the economic significance on real estate valuation of each macro variable by multiplying one standard deviation of each variable with its coefficient estimate of column 1 in Table 6 . As shown in Figure 3 for the real estate valuation on annualized basis, the most economically significant variable is lagged real estate valuation appreciation $(10.4 \%)$, then lagged decline in the current account /GDP (5.0\%), lagged growth of domestic credit/GDP (3.0\%), and lagged equity market valuation appreciation (1.5\%), for our sample of 36 countries during 2005-12. 


\section{Concluding Remarks}

Our paper confirmed a robust positive association between the appreciation of real estate valuation and increases in current account deficits and the growth rates of credit (both as fractions of the GDP) in 36 countries, covering the OECD and emerging markets, before and after the global financial crisis. While the relative impact of current account deterioration is larger than that of credit growth in our sample, one should recognize that the growth of credit/GDP is a noisy measure of the effective credit growth in the real estate market. Data limitations prevented us from controlling directly for the credit conditions in the real estate markets, and factors like the stringency of credit standards, required down payment, the effective spreads in the mortgage markets, etc. ${ }^{10}$ Thus, there is no reason to expect that the relative ranking of the importance of the current account versus the credit channels in accounting for real estate appreciations should be stable overtime. ${ }^{11}$ Yet, as theory suggests, both channels are potent. Smaller current account/GDP surpluses or larger deficits may serve as warning signals, especially when coinciding with credit expansion and real estate appreciation during the past several quarters.

Notwithstanding these results, the most important factor accounting for the appreciation of real estate turned out to be the impact of momentum: the lagged quarterly appreciations in the past year. This effect is large: a real estate appreciation of $1 \%$ in a given quarter was associated with a projected real appreciation of more than $1 \%$ in the next three quarters. ${ }^{12}$ This result is consistent with Shiller's (2000) concerns regarding Irrational Exuberance in the USA in the early

\footnotetext{
${ }^{10}$ Favilukis et al. (2012) found that credit standard variables provide the most important information in accounting for the in house price growth in the U.S. over the period 1992-2010. They made a similar, though a weaker inference for a sample of 11 OECD countries. See also Ferrero (2011) on the role of relaxation of collateral constraint on the current account-real estate price correlation, and Kuttner and Shim on the role of non-interest rate measures in the real estate markets across countries.

${ }^{11}$ In principle, counter cyclical leverage policy in the face of credit booms facilitated by hot money inflows and other factors may mitigate the impact of credit booms and raising current account deficits. Yet, the implementation of these polices is frequently subject to policy lags, and leakages allowing the private sector to bypass regulations [see Calvo (2012)]. Indeed, in the US, it took the crisis of 2008-9 to induce the tightening of the credit standards. ${ }^{12}$ The sum of the statistically significant quarterly lags is a 1.08 for the whole sample, and 1.17 for real state appreciation episodes (see Table 6). These results suggest that the momentum effect is stronger on the appreciation than the depreciation side. While this is only an approximation, it is worth noting the significance of momentum; on the predictability and momentum of real estate markets, see also Sinai (2013), Ghysels et al. (2013), and Piazzesi and Schneider (2009).
} 
2000s, with Case, Shiller, and Thompson (2012)'s findings on the significant role of expectation for demand in real estate markets, and with Glaeser, Gottlieb, and Gyourko (2013)'s questioning the role of cheap credit on real estate boom. Importantly, our results were derived in a sample of 36 countries, suggesting that Shiller's concerns apply globally. The painful adjustment in the real estate markets of the US, Spain and other affected countries in the aftermath of the crisis of 2008-9, and the key importance of momentum effects call for further research on policies that would mitigate possible bubble-dynamics.

\section{References}

Adam, Klaus, Pei Kuang and Albert Marcet (2011) "House Price Booms and the Current Account," NBER Chapters, in: NBER Macroeconomics Annual 2011 (26): 77-122.

Aizenman, Joshua and Yothin Jinjarak (2009), "Current Account Patterns and National Real Estate Markets," Journal of Urban Economics, 66(2): 75-89.

Borio, Claudio and Piti Disyatat (2011), "Current account patterns and national real estate markets Global imbalances and the financial crisis: Link or no link” BIS Working Papers Number 346.

Case, Karl E., Robert J. Shiller, and Anne K. Thompson (2012), "What have they been thinking? Homebuyer behavior in hot and cold markets," Brookings Papers on Economic Activity, 2: $265-298$.

Calvo, Guillermo (2012), “On Capital Inflows, Liquidity and Bubbles," manuscript, Columbia University.

Carroll, Christopher D., Misuzu Otsuka, and Jiri Slacalek (2011), "How large are housing and financial wealth effects? A new approach," Journal of Money, Credit, and Banking, 43(1): 55-79.

Chinn, Menzie, and Hiro Ito (2013): http://web.pdx.edu/ ito/Chinn-Ito_website.htm.

Favilukis Jack, David Kohn, Sydney C. Ludvigson and Stijn Van Nieuwerburgh (2012), "International Capital Flows and House Prices: Theory and Evidence," NBER Working Paper No. 17751.

Ferrero, Andrea, 2011, "House Prices Booms and Current Account Deficits." Unpublished paper. 
Forbes, Kristin J. and Francis E. Warnock (2012), “Capital flow waves: Surges, stops, flight, and retrenchment," Journal of International Economics, 88(2): 235-251.

Gete, Pedro (2010), "Housing Markets and Current Account Dynamics," manuscript, Georgetown University.

Ghysels, Eric, Alberto Plazzi, and Walter Torous (2013). "Forecasting Real Estate Prices," in Chapter 9, Handbook of Economic Forecasting, G. Elliott and A. Timmermann (eds.), Vol. 2, Part A: 509-580.

Glaeser, Edward L., Joshua D. Gottlieb, and Joseph Gyourko (2013), "Can cheap credit explain the housing boom?" in Housing and the Financial Crisis, E. Glaeser and T. Sinai (editors), University of Chicago Press.

Kuttner, Kenneth, and Ilhyock Shim (2013). "Can Non-Interest Rate Policies Stabilize Housing Markets? Evidence from a Panel of 57 Economies,” NBER Working Paper No. 19723.

Laven, Luc, and Fabian Valencia (2012), "Systemic Banking Crises Database: An Update," IMF Working Paper No. 12/163.

Laibson, David and Johanna Mollerstrom (2010). "Capital Flows, Consumption Booms and Asset Bubbles: A Behavioural Alternative to the Savings Glut Hypothesis," Economic Journal, 120(544): 354-374.

Leamr, Edward E. (2007). "Housing is the business cycle," Proceedings, Federal Reserve Bank of Kansas City, pages 149-233.

Obstfeld, Maurice (2012). "Does the Current Account Still Matter?" American Economic Review, 102(3): 1-23.

Piazzesi, Monika, and Martin Schneider (2009). "Momentum Traders in the Housing Market: Survey Evidence and a Search Model," American Economic Review, 99(2): 406-411.

Shiller, Robert (2000). Irrational exuberance, Princeton University Press. See also the $2^{\text {nd }}$ edition, 2005.

Sinai, Todd (2012). "House Price Moments in Boom-Bust Cycles," NBER Working Paper No. 18059.

Stock, James H. and Mark W. Watson (2012), Introduction to Econometrics, $3^{\text {rd }}$ edition, Pearson, Essex, England.

Tomura, Hajime, (2010) "International capital flows and expectation-driven boom-bust cycles in the housing market," Journal of Economic Dynamics and Control, 34(10): 1993-2009. 
Appendix A. Quarterly Data, 2005:I-2012:IV.

\begin{tabular}{|c|c|}
\hline Variable & Description \\
\hline Real estate valuation appreciation & $\begin{array}{l}\text { Nominal growth of national real estate price indices, } \\
\text { minus consumer price inflation. Source: Oxford } \\
\text { Economics, Economist Intelligence Unit (EIU). }\end{array}$ \\
\hline Current account deficit/GDP & $\begin{array}{l}\text { Current account deficits (billion US\$) divided by gross } \\
\text { domestic product (billion US\$). Source: EIU. }\end{array}$ \\
\hline Growth of domestic credit/GDP & $\begin{array}{l}\text { Bank lending (billion local currency) divided by gross } \\
\text { domestic product (billion local currency). Source: EIU. }\end{array}$ \\
\hline $\begin{array}{l}\text { Equity market valuation } \\
\text { appreciation }\end{array}$ & $\begin{array}{l}\text { Change in US\$ value of national stockmarket indices, } \\
\text { minus consumer price inflation. Source: EIU. }\end{array}$ \\
\hline CPI inflation & Consumer price inflation. Source: EIU. \\
\hline Growth of industrial production & $\begin{array}{l}\text { Change in national industrial production indices. } \\
\text { Source EIU. }\end{array}$ \\
\hline TED spread & $\begin{array}{l}\text { 3-month LIBOR (based on US\$) minus 3-month US } \\
\text { Treasury bill rate (secondary market). Source: FRED } \\
\text { (online). }\end{array}$ \\
\hline VIX & CBOE Volatility Index: VIX. Source: FRED (online). \\
\hline Sovereign CDS & $\begin{array}{l}\text { Sovereign credit default swap prices for 5-year contract } \\
\text { (basis points). Source: CMA. }\end{array}$ \\
\hline Foreign reserve accumulation & $\begin{array}{l}\text { Change in foreign-exchange reserves (billion US\$), } \\
\text { divided by gross domestic product (billion US\$). } \\
\text { Source: EIU. }\end{array}$ \\
\hline $\begin{array}{l}\text { Gross inflows and outflows of } \\
\text { capital flows and debt flows }\end{array}$ & $\begin{array}{l}\text { Changes in incurrance of liabilities and acquisition of } \\
\text { assets (million US\$). Source: IMF BOPS. }\end{array}$ \\
\hline Banking crisis incidence & $\begin{array}{l}\text { Country-specific incidence of banking crisis. Source: } \\
\text { Laeven and Valencia (2012). }\end{array}$ \\
\hline Financial openness & $\begin{array}{l}\text { Country-specific de jure measure of financial openness. } \\
\text { Source: Chinn and Ito (2013). }\end{array}$ \\
\hline Mortgage Origination in USA & $\begin{array}{l}\text { Estimates of mortgage origination in USA. Source: } \\
\text { Mortgage Bankers Association. }\end{array}$ \\
\hline
\end{tabular}

36 countries in the sample and country codes in figures. Australia:AU, Austria:AT, Belgium:BE, Bulgaria:BG, Canada:CA, China:CN, Czech Republic:CZ, Denmark:DK, Finland:FI, France:FR, Germany:DE, Greece:GR, Hong Kong:HK, Hungary:HU, Indonesia:ID, Ireland:IE, Italy:IT, Japan:JP, Korea:KR, Malaysia:MY, Netherlands:NL, New Zealand:NZ, Norway:NO, Poland:PL, Portugal:PT, Romania:RO, Singapore:SG, Slovakia:SK, South Africa:ZA, Spain:ES, Sweden:SE, Switzerland:CH, Taiwan:TW, Thailand:TH, United Kingdom:GB, United States:US 


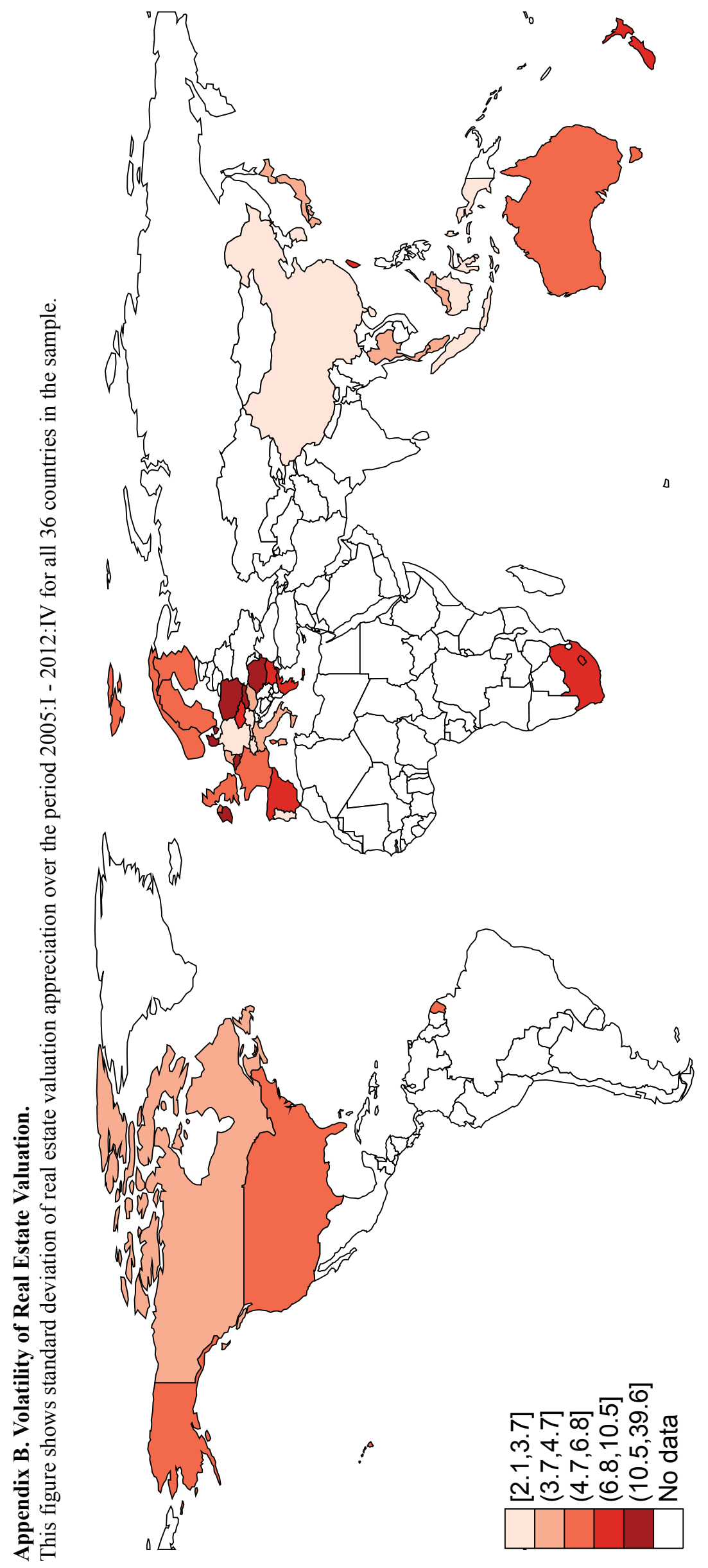




\section{Appendix C. Panel Unit Root and Cointegration Tests.}

This table reports t-statistic [1\% critical value in bracket] of Im-Pesaran-Shin test and LevinLin tests for unit root in panel data. Both tests assume that all series are non-stationary under the null hypothesis; the former is consistent under the alternative that only a fraction of the series are stationary, while the latter assumes that all series are stationary under the alternative. The panel cointegration test statistics [p-value in bracket] for real estate valuation appreciation series, current account deficit/GDP series, equity market appreciation series, and domestic credit growth series, have the null of no integration for all cross section of countries, based on Westerlund ECM tests. The tests include four lags of each variable, using quarterly data over the period 2005:I-2012:IV for all 36 countries in the sample.

\begin{tabular}{|c|c|c|}
\hline Series $\backslash$ Test & Im-Pesaran-Shin Statistic & Levin-Lin Statistic \\
\hline Real estate valuation appreciation & $-1.449[-1.810]$ & $-9.488[-0.776]$ \\
\hline Current account deficit/GDP & $-0.897[-1.810]$ & $-5.328[3.991]$ \\
\hline Growth of domestic credit/GDP & $-1.199[-1.820]$ & $-5.114[4.477]$ \\
\hline
\end{tabular}

\begin{tabular}{|c|c|c|}
\hline $\begin{array}{c}\text { Panel co-integration } \\
\text { (Westerlund Statistic) }\end{array}$ & $\begin{array}{c}\text { Real estate valuation } \\
\text { appreciation - Current } \\
\text { account deficits/GDP }\end{array}$ & $\begin{array}{c}\text { Real estate valuation } \\
\text { appreciation - Credit } \\
\text { growth/GDP }\end{array}$ \\
\hline $\begin{array}{c}\text { alternative: error correction term }<0 \\
\text { for at least one country }\end{array}$ & $-7.170[0.514]$ & $-7.649[0.317]$ \\
\hline $\begin{array}{c}\text { alternative: error correction term }<0 \\
\text { for all country }\end{array}$ & $-3.851[0.745]$ & $-1.649[1.000]$ \\
\hline
\end{tabular}

\begin{tabular}{|c|c|c|}
\hline $\begin{array}{c}\text { Panel co-integration } \\
\text { (Westerlund Statistic) }\end{array}$ & $\begin{array}{c}\text { Real estate appreciation - } \\
\text { Equity market appreciation }\end{array}$ & $\begin{array}{c}\text { Current account } \\
\text { deficit/GDP - Domestic } \\
\text { credit growth/GDP }\end{array}$ \\
\hline $\begin{array}{c}\text { alternative: error correction term }<0 \\
\text { for at least one country }\end{array}$ & $-4.969[0.993]$ & $-8.449[0.093]$ \\
\hline $\begin{array}{c}\text { alternative: error correction term }<0 \\
\text { for all country }\end{array}$ & $-4.629[0.361]$ & $-4.571[0.394]$ \\
\hline
\end{tabular}




\section{Appendix D. Empirical Specification.}

The estimation methodology is Arellano-Bond dynamic panel regression. All the variables of Tables 1-7 are in changes, denoted by $\Delta$, for both dependent and explanatory variables. The regression equation is

$$
\begin{aligned}
& \Delta[\text { Real estate appreciation - Inflation }]_{i t}=\beta_{0}+\sum_{\tau=1}^{4} \beta_{1, t-\tau} \Delta[\text { Real estate appreciation }- \text { Inflation }]_{i t-\tau} \\
& +\left\{\sum_{\tau=1}^{2} \beta_{2, t-\tau}^{0} \Delta[C A D / G D P]_{i t-\tau}\right\}^{\text {Before Break }}+\left\{\sum_{\tau=1}^{2} \beta_{2, t-\tau}^{1} \Delta[C A D / G D P]_{i t-\tau}\right\}^{\text {After Break }} \\
& +\left\{\sum_{\tau=1}^{2} \beta_{3, t-\tau}^{0} \Delta[D C R / G D P]_{i t-\tau}\right\}^{\text {Before Break }}+\left\{\sum_{\tau=1}^{2} \beta_{3, t-\tau}^{1} \Delta[D C R / G D P]_{i t-\tau}\right\}^{A f t e r ~ B r e a k} \\
& +\sum_{\tau=1}^{2} \beta_{4, t-\tau}\left\{\Delta[C A D / G D P]_{i t-\tau} \times \Delta[D C R / G D P]_{i t-\tau}\right\} \\
& +\sum_{\tau=1}^{4} \beta_{5, t-\tau} \Delta[\text { Equity market appreciation }- \text { Inflation }]_{i t-\tau} \\
& +X_{t-1}^{\prime} \theta+\varepsilon_{i t}
\end{aligned}
$$

Where $t$ denotes time (quarterly); $i$ country; CAD/GDP current-account deficit/GDP; DCR/GDP domestic credit/GDP; and $X$ denotes a vector of controls in changes, including CPI inflation, growth of industrial production, TED spread, VIX, Sovereign CDS spread, and foreign reserve accumulation. 
Table 1. Global Financial Crisis and Real Estate Appreciation.

This table reports dynamic panel estimation, using quarterly data over the period 2005:I-2012:IV. The dependent variable is $\Delta$ real estate valuation appreciation (changes in nominal price growth minus CPI inflation). The Global financial crisis's Break is a 1/0 binary variable, equals to 1 before 2007:III (Nothern Rock event) for estimation in the first column, whereas, alternatively, it is equal to 1 before 2008:III (Lehman Brothers event) in the second column; see also Figure A. The crisis breaks enter the estimation individually, as well as interaction terms with changes in current account deficit/GDP $(\triangle \mathrm{CAD} / \mathrm{GDP})$ and with changes in domestic credit/GDP $(\triangle \mathrm{DCR} / \mathrm{GDP})$ series. Standard errors are in parentheses, with $* * *(* * *)$ denotes statistical significance at $1(5,10)$ percent.

\begin{tabular}{|c|c|c|c|}
\hline Dep. Var. : $\Delta$ Real estate appreciation & \multirow{2}{*}{ lag } & $(1)$ & $(2)$ \\
\hline & & coefficient (std err) & coefficient (std err) \\
\hline \multirow{4}{*}{$\Delta$ Real estate valuation appreciation } & 1 & $0.63(0.02)^{* * *}$ & $0.63(0.02)^{* * *}$ \\
\hline & 2 & $0.64(0.04)^{* * *}$ & $0.62(0.04)^{* * *}$ \\
\hline & 3 & $-0.20(0.06)^{* * *}$ & $-0.19(0.06)^{* * *}$ \\
\hline & 4 & $0.00(0.03)$ & $-0.00(0.03)$ \\
\hline Before Global financial crisis's Break & binary $(1 / 0)$ & $2.35(1.47)$ & $-1.68(1.05)$ \\
\hline \multirow[t]{2}{*}{$\Delta \mathrm{CAD} / \mathrm{GDP} \times$ Before Break } & 1 & $1.40(0.90)$ & $-1.58(0.79)^{* *}$ \\
\hline & 2 & $1.53(0.77)^{* *}$ & $2.65(0.68)^{* * *}$ \\
\hline \multirow[t]{2}{*}{$\Delta \mathrm{CAD} / \mathrm{GDP} \times$ After Break } & 1 & $0.33(0.65)$ & $0.55(0.66)$ \\
\hline & 2 & $1.92(0.65)^{* * *}$ & $1.91(0.66)^{* * *}$ \\
\hline \multirow[t]{2}{*}{$\Delta \mathrm{DCR} / \mathrm{GDP} \times$ Before Break } & 1 & $1.37(0.39)^{* * *}$ & $0.88(0.33)^{* * *}$ \\
\hline & 2 & $-0.35(0.26)$ & $-0.32(0.25)$ \\
\hline \multirow[t]{2}{*}{$\Delta \mathrm{DCR} / \mathrm{GDP} \times$ After Break } & 1 & $0.19(0.19)$ & $0.16(0.19)$ \\
\hline & 2 & $0.17(0.14)$ & $0.16(0.14)$ \\
\hline \multirow[t]{2}{*}{$\Delta \mathrm{CAD} / \mathrm{GDP} \times \triangle \mathrm{DCR} / \mathrm{GDP}$} & 1 & $-0.02(0.01)$ & $-0.01(0.01)$ \\
\hline & 2 & $0.00(0.01)$ & $0.00(0.01)$ \\
\hline \multirow[t]{4}{*}{$\Delta$ Equity market valuation appreciation } & 1 & $0.21(0.04)^{* * *}$ & $0.21(0.04)^{* * *}$ \\
\hline & 2 & $-0.16(0.07)^{* *}$ & $-0.14(0.07)^{*}$ \\
\hline & 3 & $0.07(0.06)$ & $0.07(0.06)$ \\
\hline & 4 & $-0.00(0.02)$ & $-0.00(0.02)$ \\
\hline$\Delta \mathrm{CPI}$ inflation & 1 & $-0.95(0.50)^{*}$ & $-1.18(0.51)^{* *}$ \\
\hline \multirow{2}{*}{$\begin{array}{l}\Delta \text { Growth of industrial production } \\
\Delta \text { TED spread }\end{array}$} & 1 & $-0.09(0.10)$ & $-0.07(0.10)$ \\
\hline & 1 & $2.06(1.75)$ & $0.99(1.71)$ \\
\hline$\Delta \mathrm{VIX}$ & 1 & $-0.05(0.09)$ & $0.11(0.10)$ \\
\hline$\Delta$ Sovereign CDS & 1 & $-0.07(0.22)$ & $-0.11(0.22)$ \\
\hline \multirow{2}{*}{$\begin{array}{l}\text { Foreign reserve accumulation } \\
\text { constant }\end{array}$} & 1 & $0.06(0.06)$ & $0.08(0.06)$ \\
\hline & 0 & $-0.77(0.51)$ & $-0.05(0.57)$ \\
\hline \multirow{2}{*}{$\begin{array}{l}\text { observations } \\
\text { Arellano-Bond AR(2) test p-val }\end{array}$} & & 791 & 791 \\
\hline & & 0.084 & \\
\hline
\end{tabular}


Table 2. Turning Points of Current Account Deficit/GDP and Growth of Domestic Credit/GDP.

This table reports dynamic panel estimation (first column) and fixed-effect estimation (second column), using quarterly data over the period 2005:I-2012:IV. The dependent variable is $\Delta$ real estate valuation appreciation (nominal price growth minus CPI inflation). Instead of using a Global crisis binary variable as done in Table 1, this table uses a new binary variable "Current account deficit/GDP's Break" to identify country-specific turning point in the association between real estate appreciation and current account deficit/GDP, according to QLR statistics; "Growth of domestic credit/GDP's Break" is defined similarly for stock of domestic credit/GDP; see also Figure 2. These country-specific breaks enter the estimation individually, and as interaction terms with $\triangle \mathrm{CAD} / \mathrm{GDP}$ and $\triangle \mathrm{DCR} / \mathrm{GDP}$ series. Standard errors in parentheses, with $* * *(* * *)$ for significance at $1(5,10)$ percent.

\begin{tabular}{|c|c|c|c|}
\hline Dep. Var. : $\Delta$ Real estate appreciation & lag & Dynamic panel estimation & $\begin{array}{c}(2) \\
\text { Fixed-effect estimation }\end{array}$ \\
\hline Regressors & & coefficient (std. err.) & coefficient (std. err.) \\
\hline$\Delta$ Real estate valuation appreciation & $\begin{array}{l}1 \\
2 \\
3 \\
4\end{array}$ & $\begin{array}{l}0.64(0.02) * * * \\
0.62(0.04) * * * \\
-0.17(0.06) * * * \\
-0.01(0.03)\end{array}$ & $\begin{array}{l}0.63(0.02) * * * \\
0.65(0.05) * * * \\
-0.19(0.07) * * * \\
-0.01(0.03)\end{array}$ \\
\hline $\begin{array}{r}\text { Current account deficit/GDP's Break } \\
\Delta \mathrm{CAD} / \mathrm{GDP} \times \text { Before Break } \\
\Delta \mathrm{CAD} / \mathrm{GDP} \times \text { After Break }\end{array}$ & $\begin{array}{c}\text { binary (1/0) } \\
1 \\
2 \\
1 \\
2\end{array}$ & $\begin{array}{l}0.80(1.18) \\
0.09(0.73) \\
2.11(0.69)^{* * *} \\
0.38(0.66) \\
1.99(0.65)^{* * *}\end{array}$ & $\begin{array}{l}2.93(1.53)^{*} \\
0.21(0.69) \\
1.49(0.64)^{* *} \\
0.23(0.63) \\
1.56(0.61)^{* *}\end{array}$ \\
\hline $\begin{array}{r}\text { Growth of domestic credit/GDP's Break } \\
\Delta \mathrm{DCR} / \mathrm{GDP} \times \text { Before Break } \\
\Delta \mathrm{DCR} / \mathrm{GDP} \times \text { After Break }\end{array}$ & $\begin{array}{c}\text { binary }(1 / 0) \\
1 \\
2 \\
1 \\
2\end{array}$ & $\begin{array}{r}-1.67(1.22) \\
0.36(0.29) \\
-0.01(0.20) \\
0.19(0.20) \\
0.18(0.15) \\
\end{array}$ & $\begin{array}{r}-1.45(1.45) \\
0.20(0.21) \\
0.00(0.15) \\
0.04(0.18) \\
0.15(0.14) \\
\end{array}$ \\
\hline $\begin{array}{l}\Delta \mathrm{CAD} / \mathrm{GDP} \times \Delta \mathrm{DCR} / \mathrm{GDP} \mid \text { Before Break } \\
\Delta \mathrm{CAD} / \mathrm{GDP} \times \Delta \mathrm{DCR} / \mathrm{GDP} \mid \text { After Break } \\
\end{array}$ & $\begin{array}{l}1 \\
1 \\
\end{array}$ & $\begin{array}{l}-0.01(0.01) \\
-0.00(0.01) \\
\end{array}$ & $\begin{array}{l}-0.01(0.01) \\
-0.00(0.01) \\
\end{array}$ \\
\hline$\Delta$ Equity market valuation appreciation & $\begin{array}{l}1 \\
2 \\
3 \\
4\end{array}$ & $\begin{array}{l}0.21(0.04)^{* * *} \\
-0.15(0.07)^{* *} \\
0.07(0.06) \\
-0.00(0.02)\end{array}$ & $\begin{array}{l}0.15(0.04) * * * \\
-0.09(0.07) \\
0.02(0.06) \\
0.01(0.02)\end{array}$ \\
\hline $\begin{array}{l}\Delta \text { CPI inflation } \\
\Delta \text { Growth of industrial production } \\
\Delta \text { TED spread } \\
\Delta \text { VIX } \\
\Delta \text { Sovereign CDS } \\
\text { Foreign reserve accumulation } \\
\text { constant }\end{array}$ & $\begin{array}{l}1 \\
1 \\
1 \\
1 \\
1 \\
1 \\
0\end{array}$ & $\begin{array}{l}-1.23(0.50)^{* *} \\
-0.07(0.10) \\
0.66(1.70) \\
-0.01(0.08) \\
-0.10(0.23) \\
0.04(0.06) \\
-0.32(0.66) \\
\end{array}$ & $\begin{array}{r}-0.40(0.46) \\
-0.08(0.09) \\
0.41(1.68) \\
-0.01(0.08) \\
-0.05(0.27) \\
0.04(0.06) \\
-1.40(0.73)^{*} \\
\end{array}$ \\
\hline $\begin{array}{l}\text { observations } \\
\text { Arellano-Bond AR(2) test p-value }\end{array}$ & & 791 & $\begin{array}{r}791 \\
\mathrm{R}^{2}=0.81\end{array}$ \\
\hline
\end{tabular}


Table 3. Current Account Deficit vis-à-vis Growth of Domestic Credit on Real Estate Valuation. This table reports dynamic panel estimation, using quarterly data over the period 2005:I-2012:IV. The dependent variable is $\Delta$ real estate valuation appreciation (nominal price growth minus CPI inflation). Standard errors are in parentheses, with $* * *(* *, *)$ denotes statistical significance at $1(5,10)$ percent.

\begin{tabular}{|c|c|c|c|}
\hline Dep. Var. : $\Delta$ Real estate appreciation & \multirow{2}{*}{ lag } & (1) & (2) \\
\hline Regressors & & coefficient (std. err.) & coefficient (std. err.) \\
\hline \multirow[t]{4}{*}{$\Delta$ Real estate valuation appreciation } & 1 & $0.64(0.02)^{* * * *}$ & $0.64(0.02)^{* * *}$ \\
\hline & 2 & $0.63(0.04)^{* * *}$ & $0.61(0.04)^{* * *}$ \\
\hline & 3 & $-0.18(0.06)^{* * *}$ & $-0.15(0.06)^{* *}$ \\
\hline & 4 & $-0.01(0.03)$ & $-0.02(0.03)$ \\
\hline \multirow{4}{*}{$\Delta$ Current account deficit/GDP } & 1 & $-0.56(0.75)$ & \\
\hline & 2 & $5.33(1.64)^{* * *}$ & \\
\hline & 3 & $-3.02(1.67)^{*}$ & \\
\hline & 4 & $0.56(0.61)$ & \\
\hline \multirow[t]{4}{*}{$\Delta$ Growth of domestic credit/GDP } & 1 & & $0.15(0.23)$ \\
\hline & 2 & & $0.23(0.45)$ \\
\hline & 3 & & $-0.18(0.40)$ \\
\hline & 4 & & $0.08(0.14)$ \\
\hline \multirow[t]{4}{*}{$\Delta$ Equity market valuation appreciation } & 1 & $0.20(0.04)^{* * *}$ & $0.23(0.04)^{* * *}$ \\
\hline & 2 & $-0.13(0.07)^{*}$ & $-0.17(0.07)^{* *}$ \\
\hline & 3 & $0.06(0.06)$ & $0.08(0.06)$ \\
\hline & 4 & $-0.00(0.02)$ & $-0.01(0.02)$ \\
\hline$\Delta$ CPI inflation & 1 & $-1.25(0.49)^{* *}$ & $-1.20(0.50)^{* *}$ \\
\hline$\Delta$ Growth of industrial production & 1 & $-0.04(0.10)$ & $-0.08(0.10)$ \\
\hline$\Delta$ TED spread & 1 & $0.58(1.70)$ & $1.42(1.68)$ \\
\hline$\Delta \mathrm{VIX}$ & 1 & $-0.02(0.08)$ & $-0.02(0.08)$ \\
\hline$\Delta$ Sovereign CDS & 1 & $-0.06(0.22)$ & $-0.08(0.22)$ \\
\hline Foreign reserve accumulation & 1 & $0.06(0.06)$ & $0.06(0.06)$ \\
\hline constant & 0 & $-1.05(0.44)^{* *}$ & $-0.93(0.44)^{* *}$ \\
\hline $\begin{array}{l}\text { observations } \\
\text { Arellano-Bond AR(2) test p-value }\end{array}$ & & 765 & 765 \\
\hline
\end{tabular}


Table 4. Reverse Feedback of Real Estate Appreciation to Current Account and Equity Market. This table reports dynamic panel estimation, using quarterly data over the period 2005:I-2012:IV. The dependent variable is $\Delta$ current account deficit/GDP in the first column and $\Delta$ equity market appreciation in the second column. The Global financial crisis's Break is a $1 / 0$ binary variable, equals to 1 before 2007:III (Nothern Rock event); see also Figure 2. The crisis break enters the estimation individually, and as interaction terms with real estate appreciation/CPI series. Standard errors are in parentheses, with $* * *(* *, *)$ denotes statistical significance at $1(5,10)$ percent.

\begin{tabular}{|c|c|c|c|}
\hline & lag & $\begin{array}{c}(1) \\
\Delta \mathrm{CAD} / \mathrm{GDP}\end{array}$ & $\begin{array}{c}(2) \\
\Delta \text { Equity Appreciation }\end{array}$ \\
\hline Regressors & & coefficient (std. err.) & coefficient (std. err.) \\
\hline \multirow[t]{4}{*}{$\Delta \mathrm{CAD} / \mathrm{GDP}$} & 1 & $0.40(0.04)^{* * *}$ & $-3.87(1.42)^{* * *}$ \\
\hline & 2 & $0.61(0.08)^{* * *}$ & $0.87(3.28)$ \\
\hline & 3 & $-0.91(0.08) * * *$ & $-1.48(3.38)$ \\
\hline & 4 & $0.33(0.03)^{* * *}$ & $0.34(1.24)$ \\
\hline Before Global financial crisis's Break & binary $(1 / 0)$ & $0.17(0.10)^{*}$ & $4.87(2.19)^{* *}$ \\
\hline \multirow{2}{*}{$\Delta$ Real estate appreciation $\times$ Before Break } & 1 & $-0.01(0.02)$ & $1.46(0.67)^{* *}$ \\
\hline & 2 & $-0.05(0.02)^{* *}$ & $-0.07(0.73)$ \\
\hline \multirow[t]{2}{*}{$\Delta$ Real estate appreciation $\times$ After Break } & 1 & $-0.04(0.01)^{* * *}$ & $1.02(0.42)^{* *}$ \\
\hline & 2 & $-0.01(0.02)$ & $-0.01(0.58)$ \\
\hline \multirow[t]{4}{*}{$\Delta$ Equity market valuation appreciation } & 1 & $0.00(0.00)$ & $-0.56(0.07)^{* * *}$ \\
\hline & 2 & $0.00(0.00)$ & $1.43(0.13)^{* * *}$ \\
\hline & 3 & $-0.00(0.00)$ & $-1.24(0.11)^{* * *}$ \\
\hline & 4 & $0.00(0.00)$ & $0.41(0.03)^{* * *}$ \\
\hline$\Delta \mathrm{CPI}$ inflation & 1 & $0.06(0.03)^{* *}$ & $-6.19(0.95)^{* * *}$ \\
\hline$\Delta$ Growth of industrial production & 1 & $0.01(0.01)^{*}$ & $0.56(0.19)^{* * *}$ \\
\hline$\Delta$ TED spread & 1 & $0.20(0.11)^{*}$ & $-12.64(3.15)^{* * *}$ \\
\hline$\Delta \mathrm{VIX}$ & 1 & $-0.01(0.01)$ & $0.01(0.16)$ \\
\hline$\Delta$ Sovereign CDS & 1 & $-0.02(0.01)$ & $-0.72(0.43)^{*}$ \\
\hline Foreign reserve accumulation & 1 & $0.01(0.00)^{* *}$ & $0.22(0.12)^{*}$ \\
\hline constant & 0 & $-0.07(0.03)^{* *}$ & $-2.30(0.96)^{* *}$ \\
\hline observations & & 789 & 791 \\
\hline Arellano-Bond AR(2) test p-value & & 0.921 & 0.600 \\
\hline
\end{tabular}


Table 5. Appreciation vis-à-vis Depreciation Episodes of Real Estate Valuation.

This table reports dynamic panel estimation on the episode of real estate market appreciation in the first column and on the episode of real estate market depreciation in the second column, using quarterly data over the period 2005:I-2012:IV. The dependent variable is $\Delta$ real estate valuation appreciation (nominal price growth minus CPI inflation). Instead of using a Global crisis binary variable, as in Table 2 this table uses a binary variable "Current account deficit/GDP's Break" to identify country-specific turning point in the association between real estate appreciation and current account deficit/GDP, according to QLR statistics; "Domestic credit/GDP's Break" is defined similarly for growth of domestic credit/GDP; see also Figure 2. The country-specific breaks enter the estimation individually, and as interaction terms with $\triangle \mathrm{CAD} / \mathrm{GDP}$ and $\triangle \mathrm{DCR} / \mathrm{GDP}$ series. Constant term included, not reported. Standard errors in parentheses; $* * *(* *, *)$ denotes significance at $1(5,10)$

\begin{tabular}{|c|c|c|c|}
\hline Dep. Var. : $\Delta$ Real estate appreciation & lag & $\begin{array}{c}\text { (1) } \\
\text { Appreciation Episodes }\end{array}$ & $\begin{array}{c}(2) \\
\text { Depreciation Episodes }\end{array}$ \\
\hline Regressors & & coefficient (std. err.) & coefficient (std. err.) \\
\hline$\Delta$ Real estate valuation appreciation & $\begin{array}{l}1 \\
2 \\
3 \\
4\end{array}$ & $\begin{array}{r}0.60(0.03) * * * \\
0.87(0.07) * * * \\
-0.29(0.10) * * * \\
0.03(0.05)\end{array}$ & $\begin{array}{l}0.65(0.03) * * * \\
0.54(0.05) * * * \\
-0.20(0.07) * * * \\
0.00(0.04)\end{array}$ \\
\hline $\begin{array}{r}\text { Current account deficit/GDP's Break } \\
\Delta \mathrm{CAD} / \mathrm{GDP} \times \text { Before Break } \\
\Delta \mathrm{CAD} / \mathrm{GDP} \times \text { After Break }\end{array}$ & \begin{tabular}{|c|} 
binary (1/0) \\
1 \\
2 \\
1 \\
2
\end{tabular} & $\begin{aligned} & 2.26(1.46) \\
&-0.86(0.88) \\
& 2.83(0.90)^{* * *} \\
&-0.75(0.81) \\
& 2.70(0.81)^{* * *}\end{aligned}$ & $\begin{array}{l}0.68(1.33) \\
0.35(0.85) \\
0.32(0.79) \\
0.79(0.76) \\
0.25(0.77)\end{array}$ \\
\hline $\begin{array}{r}\text { Growth of domestic credit/GDP's Break } \\
\Delta \mathrm{DCR} / \mathrm{GDP} \times \text { Before Break } \\
\Delta \mathrm{DCR} / \mathrm{GDP} \times \text { After Break }\end{array}$ & $\begin{array}{c}\text { binary (1/0) } \\
1 \\
2 \\
1 \\
2 \\
\end{array}$ & $\begin{array}{r}-1.23(1.44) \\
0.13(0.40) \\
0.27(0.26) \\
-0.08(0.27) \\
0.54(0.21)^{* *} \\
\end{array}$ & $\begin{array}{r}-1.25(1.31) \\
0.15(0.24) \\
-0.08(0.17) \\
0.36(0.22) \\
-0.14(0.16) \\
\end{array}$ \\
\hline $\begin{array}{l}\Delta \mathrm{CAD} / \mathrm{GDP} \times \Delta \mathrm{DCR} / \mathrm{GDP} \mid \text { Before Break } \\
\Delta \mathrm{CAD} / \mathrm{GDP} \times \Delta \mathrm{DCR} / \mathrm{GDP} \mid \text { After Break } \\
\end{array}$ & $\begin{array}{l}1 \\
1 \\
\end{array}$ & $\begin{array}{l}-0.01(0.01) \\
-0.01(0.01) \\
\end{array}$ & $\begin{array}{l}-0.00(0.01) \\
-0.01(0.01) \\
\end{array}$ \\
\hline$\Delta$ Equity market valuation appreciation & $\begin{array}{l}1 \\
2 \\
3 \\
4\end{array}$ & $\begin{array}{r}0.08(0.06) \\
0.00(0.10) \\
-0.03(0.08) \\
0.02(0.03)\end{array}$ & $\begin{array}{l}0.24(0.04)^{* * *} \\
-0.21(0.07)^{* * *} \\
0.09(0.06) \\
-0.01(0.02)\end{array}$ \\
\hline $\begin{array}{l}\Delta \text { CPI inflation } \\
\Delta \text { Growth of industrial production } \\
\Delta \text { TED spread } \\
\Delta \text { VIX } \\
\Delta \text { Sovereign CDS } \\
\text { Foreign reserve accumulation }\end{array}$ & $\begin{array}{l}1 \\
1 \\
1 \\
1 \\
1 \\
1\end{array}$ & $\begin{array}{r}0.11(0.74) \\
-0.17(0.14) \\
-2.89(2.80) \\
-0.04(0.14) \\
-1.62(1.98) \\
0.01(0.07)\end{array}$ & $\begin{array}{l}-1.13(0.47)^{* *} \\
-0.08(0.10) \\
0.89(1.80) \\
-0.03(0.09) \\
-0.14(0.22) \\
-0.04(0.08)\end{array}$ \\
\hline $\begin{array}{l}\text { observations } \\
\text { Arellano-Bond AR(2) test p-value }\end{array}$ & & $\begin{array}{r}367 \\
0.495\end{array}$ & 424 \\
\hline
\end{tabular}


Table 6. Benchmark Results.

This table reports dynamic panel estimation, using quarterly data over the period 2005:I-2012:IV. The dependent variable is $\Delta$ real estate valuation appreciation (nominal price growth minus CPI inflation). The empirical specification is similar to that of Table 1 columm (1), but in this table both lagged $\Delta$ real estate appreciation and lagged $\Delta$ equity market appreciation are endogenous regressors. The Global financial crisis's Break is a 1/0 binary variable, equals to 1 before 2007:III (Nothern Rock event) for estimation; see also Figure A. The crisis breaks enter the estimation individually, as well as interaction terms with current account deficit/GDP ( $\triangle \mathrm{CAD} / \mathrm{GDP})$ and with domestic credit/GDP $(\triangle \mathrm{DCR} / \mathrm{GDP})$ series. Standard errors in parentheses, with *** $\left(* *,^{*}\right)$ denotes statistical significance at $1(5,10)$ percent.

\begin{tabular}{|c|c|c|c|}
\hline Dep. Var. : $\Delta$ Real estate appreciation & \multirow[t]{2}{*}{ lag } & $\begin{array}{c}\text { (1) } \\
\text { Whole Sample }\end{array}$ & $\begin{array}{c}(2) \\
\text { Appreciation Episodes }\end{array}$ \\
\hline Regressors & & coefficient (std. err.) & coefficient (std. err.) \\
\hline \multirow[t]{4}{*}{$\Delta$ Real estate valuation appreciation } & 1 & $0.63(0.02)^{* * *}$ & $0.60(0.03)^{* * *}$ \\
\hline & 2 & $0.65(0.04)^{* * *}$ & $0.88(0.07)^{* * *}$ \\
\hline & 3 & $-0.20(0.06) * * *$ & $-0.31(0.10) * * *$ \\
\hline & 4 & $-0.00(0.03)$ & $0.03(0.05)$ \\
\hline Before Global financial crisis's Break & binary (1/0) & $1.82(1.06)^{*}$ & $1.93(1.32)$ \\
\hline \multirow[t]{2}{*}{$\Delta \mathrm{CAD} / \mathrm{GDP} \times$ Before Break } & 1 & $0.79(0.68)$ & $0.02(0.83)$ \\
\hline & 2 & $1.50(0.61)^{* *}$ & $1.98(0.82)^{* *}$ \\
\hline \multirow[t]{2}{*}{$\Delta \mathrm{CAD} / \mathrm{GDP} \times$ After Break } & 1 & $0.35(0.55)$ & $-0.59(0.75)$ \\
\hline & 2 & $1.67(0.55)^{* * *}$ & $2.29(0.78)^{* * *}$ \\
\hline \multirow[t]{2}{*}{$\triangle \mathrm{DCR} / \mathrm{GDP} \times$ Before Break } & 1 & $0.81(0.27)^{* * *}$ & $0.36(0.36)$ \\
\hline & 2 & $-0.19(0.19)$ & $0.22(0.25)$ \\
\hline \multirow[t]{2}{*}{$\triangle \mathrm{DCR} / \mathrm{GDP} \times$ After Break } & 1 & $0.12(0.15)$ & $-0.04(0.25)$ \\
\hline & 2 & $0.11(0.11)$ & $0.42(0.20)^{* *}$ \\
\hline$\Delta \mathrm{CAD} / \mathrm{GDP} \times \triangle \mathrm{DCR} / \mathrm{GDP} \mid$ Before Break & 1 & $-0.01(0.01)$ & $-0.01(0.01)$ \\
\hline$\Delta \mathrm{CAD} / \mathrm{GDP} \times \Delta \mathrm{DCR} / \mathrm{GDP} \mid$ After Break & 1 & $-0.00(0.01)$ & $-0.00(0.01)$ \\
\hline \multirow[t]{4}{*}{$\Delta$ Equity market valuation appreciation } & 1 & $0.15(0.03)^{* * *}$ & $0.07(0.05)$ \\
\hline & 2 & $-0.10(0.06)$ & $0.01(0.10)$ \\
\hline & 3 & $0.03(0.05)$ & $-0.03(0.08)$ \\
\hline & 4 & $0.01(0.02)$ & $0.02(0.03)$ \\
\hline$\Delta \mathrm{CPI}$ & 1 & $-0.53(0.42)$ & $0.24(0.71)$ \\
\hline$\Delta$ Growth of industrial production & 1 & $-0.06(0.08)$ & $-0.15(0.13)$ \\
\hline$\Delta \mathrm{TED}$ spread & 1 & $1.52(1.56)$ & $-0.96(2.81)$ \\
\hline$\Delta \mathrm{VIX}$ & 1 & $-0.04(0.08)$ & $-0.08(0.14)$ \\
\hline$\Delta$ Sovereign CDS & 1 & $-0.10(0.21)$ & $-1.16(1.91)$ \\
\hline \multirow{2}{*}{$\begin{array}{l}\text { Foreign reserve accumulation } \\
\text { constant }\end{array}$} & 1 & $0.05(0.05)$ & $0.02(0.07)$ \\
\hline & 0 & $-0.95(0.47)^{* *}$ & $-1.18(0.77)$ \\
\hline \multirow{2}{*}{\begin{tabular}{|l|} 
observations \\
Arellano-Bond AR(2) test p-value
\end{tabular}} & & 791 & 367 \\
\hline & & 0.495 & 0.468 \\
\hline
\end{tabular}


Table 7. Additional Results.

This table reports dynamic panel estimation, using quarterly data over the period 2005:I-2012:IV. The dependent variable is $\Delta$ real estate valuation appreciation (nominal price growth minus CPI inflation). The empirical specification is similar to that of Table 1 columm (1), but in this table both lagged $\Delta$ real estate appreciation and lagged $\Delta$ equity market appreciation are endogenous regressors. The Global financial crisis's Break is a $1 / 0$ binary variable, equals to 1 before 2007:III (Nothern Rock event) for estimation; see also Figure A. The crisis breaks enter the estimation individually, as well as interaction terms with current account deficit/GDP ( $\triangle \mathrm{CAD} / \mathrm{GDP})$ and with domestic credit/GDP ( $\triangle \mathrm{DCR} / \mathrm{GDP})$ series. Standard errors in parentheses, with $* * *(* * *)$ denotes statistical significance at $1(5,10)$ percent.

\begin{tabular}{|c|c|c|c|c|c|c|c|c|}
\hline Dep. Var. : $\Delta$ Real estate appreciation & \multirow[t]{2}{*}{ lag } & $\begin{array}{c}(1) \\
\mathrm{CAD}=\text { Gross Inflows }\end{array}$ & $\begin{array}{c}\text { (2) } \\
\text { CAD=Inflows+Outflows }\end{array}$ & $\begin{array}{c}\text { (3) } \\
\mathrm{CAD}=\text { Debt Inflows }\end{array}$ & $\begin{array}{c}\text { (4) } \\
\mathrm{CAD}=\text { Net Debt Flows }\end{array}$ & $\begin{array}{c}\text { (5) } \\
\text { CAD=Debt In+Outflows }\end{array}$ & $\begin{array}{c}\text { (6) } \\
\text { Banking Crisis Group }\end{array}$ & \begin{tabular}{|c|}
$(7)$ \\
No Banking Crisis Group
\end{tabular} \\
\hline \multirow{5}{*}{\begin{tabular}{|l} 
Regressors \\
$\Delta$ Real estate valuation appreciation
\end{tabular}} & & \begin{tabular}{|l} 
coefficient (std. err.) \\
\end{tabular} & coefficient (std. err.) & coefficient (std. err.) & coefficient (std. err.) & \begin{tabular}{|l} 
coefficient (std. err.) \\
\end{tabular} & coefficient (std. err.) & \begin{tabular}{|l} 
coefficient (std. err.) \\
\end{tabular} \\
\hline & 1 & $0.70(0.02)^{* * * *}$ & $0.70(0.02)^{* * *}$ & $0.71(0.02)^{* * * *}$ & $0.71(0.02)^{* * * *}$ & $0.71(0.02)^{* * * *}$ & $0.62(0.02)^{* * *}$ & $0.64(0.03)^{* * * *}$ \\
\hline & 2 & $0.57(0.04)^{* * *}$ & $0.57(0.04)^{* * *}$ & $0.60(0.04)^{* * * *}$ & $0.79(0.05)^{* * * *}$ & $0.80(0.05)^{* * * *}$ & $0.89(0.05)^{* * *}$ & $0.58(0.06)^{* * *}$ \\
\hline & 3 & $-0.08(0.06)$ & $-0.08(0.06)$ & $-0.13(0.06)^{* *}$ & $-0.11(0.08)$ & $-0.11(0.08)$ & $-0.39(0.08)^{* * *}$ & $-0.16(0.08)^{*}$ \\
\hline & 4 & $-0.04(0.03)$ & $-0.04(0.03)$ & $-0.01(0.03)$ & $0.02(0.04)$ & $0.03(0.04)$ & $0.10(0.04)^{* *}$ & $-0.01(0.04)$ \\
\hline Before Global financial crisis's Break & binary $(100)$ & $2.32(1.22)^{*}$ & $2.30(1.22)^{*}$ & $1.92(0.93)^{* * *}$ & $2.88(1.04)^{* * * *}$ & $2.83(1.03)^{* * * *}$ & $-0.59(0.88)$ & $4.08(1.85)^{* * *}$ \\
\hline \multirow[t]{2}{*}{$\Delta \mathrm{CAD} / \mathrm{GDP} \times$ Before Breal } & 1 & $1.82(3.35)$ & $1.05(1.73)$ & $5.01(26.34)$ & $5.83(19.99)$ & $9.38(19.68)$ & $-0.33(0.68)$ & $1.66(0.95)^{*}$ \\
\hline & 2 & $-0.48(1.88)$ & $-0.31(0.98)$ & $-9.21(14.84)$ & $-10.22(11.44)$ & $-19.43(11.57)^{*}$ & $0.91(0.63)$ & $1.21(0.88)$ \\
\hline \multirow[t]{2}{*}{$\Delta \mathrm{CAD} / \mathrm{GDP} \times$ After Break } & 1 & $0.39(0.94)$ & $0.24(0.49)$ & $-1.62(6.29)$ & $-0.50(5.12)$ & $6.32(5.24)$ & $-0.24(0.58)$ & $0.97(0.83)$ \\
\hline & 2 & $-0.14(0.53)$ & $-0.08(0.28)$ & $-0.26(3.59)$ & $-1.50(2.96)$ & $-4.74(3.02)$ & $0.63(0.59)$ & $1.65(0.81)^{* *}$ \\
\hline \multirow[t]{2}{*}{$\Delta \mathrm{DCR} / \mathrm{GDP} \times$ Before Break } & 1 & $0.89(0.28)^{* * * *}$ & $0.89(0.28)^{* * * *}$ & $0.77(0.23)^{* * * *}$ & $0.68(0.23)^{* * * *}$ & $0.71(0.23)^{* * * *}$ & $0.46(0.19)^{* * *}$ & $1.11(0.54)^{* * *}$ \\
\hline & 2 & $-0.26(0.19)$ & $-0.26(0.19)$ & $-0.34(0.16)^{* *}$ & $-0.29(0.15)^{*}$ & $-0.26(0.15)^{*}$ & $-0.27(0.13)^{* * *}$ & $-0.01(0.36)$ \\
\hline \multirow[t]{2}{*}{$\Delta \mathrm{DCR} / \mathrm{GDP} \times$ After Break } & 1 & $0.01(0.15)$ & $0.01(0.15)$ & $0.03(0.14)$ & $0.00(0.14)$ & $0.02(0.14)$ & $0.10(0.11)$ & $-0.03(0.30)$ \\
\hline & 2 & $0.08(0.12)$ & $0.07(0.12)$ & $0.06(0.11)$ & $0.02(0.10)$ & $0.02(0.10)$ & $-0.04(0.08)$ & $0.47(0.24)^{*}$ \\
\hline \multirow[t]{4}{*}{$\Delta$ Equity market valuation appreciation } & 1 & $0.08(0.04)^{*}$ & $0.08(0.04)^{*}$ & $0.10(0.03)^{* * *}$ & $0.05(0.04)$ & $0.05(0.04)$ & $0.14(0.04)^{* * * *}$ & $0.15(0.05)^{* * * *}$ \\
\hline & 2 & $-0.00(0.07)$ & $-0.00(0.07)$ & $-0.02(0.06)$ & $-0.00(0.07)$ & $0.01(0.07)$ & $-0.18(0.06)^{* * * *}$ & $-0.02(0.10)$ \\
\hline & 3 & $-0.01(0.06)$ & $-0.02(0.06)$ & $-0.01(0.05)$ & $0.02(0.06)$ & $0.02(0.06)$ & $0.14(0.05)^{* * * *}$ & $-0.06(0.08)$ \\
\hline & 4 & $0.01(0.02)$ & $0.01(0.02)$ & $0.02(0.01)$ & $-0.00(0.02)$ & $-0.00(0.02)$ & $-0.03(0.02)^{*}$ & $0.04(0.03)$ \\
\hline$\Delta \mathrm{CPI}$ inflation & 1 & $-0.32(0.53)$ & $-0.30(0.53)$ & $0.37(0.43)$ & $1.48(0.59)^{* * *}$ & $1.45(0.58)^{* * *}$ & $-0.14(0.51)$ & $-0.12(0.60)$ \\
\hline \multirow{2}{*}{$\begin{array}{l}\Delta \text { Growth of industrial production } \\
\Delta \text { TED spread }\end{array}$} & 1 & $0.38(0.13)^{* * * *}$ & $0.38(0.13)^{* * *}$ & $0.16(0.10)$ & $0.15(0.12)$ & $0.14(0.11)$ & $-0.03(0.10)$ & $-0.15(0.12)$ \\
\hline & 1 & $3.20(1.67)^{*}$ & $3.18(1.67)^{*}$ & $2.95(1.44)^{* *}$ & $1.75(1.66)$ & $1.62(1.63)$ & $1.49(1.35)$ & $-0.98(2.88)$ \\
\hline$\Delta$ VIX & 1 & $-0.03(0.08)$ & $-0.03(0.08)$ & $-0.04(0.07)$ & $-0.06(0.08)$ & $-0.06(0.08)$ & $-0.06(0.07)$ & $0.03(0.14)$ \\
\hline$\Delta$ Sovereign CDS & 1 & $-0.11(0.18)$ & $-0.11(0.18)$ & $-0.12(0.17)$ & $-0.06(0.15)$ & $-0.06(0.15)$ & $-0.08(0.13)$ & $-1.57(1.45)$ \\
\hline \multirow{2}{*}{$\begin{array}{l}\text { Foreign reserve accumulation } \\
\text { constant }\end{array}$} & 1 & $0.02(0.06)$ & $0.02(0.06)$ & $0.02(0.05)$ & $0.07(0.06)$ & $0.07(0.06)$ & $0.03(0.05)$ & $0.04(0.09)$ \\
\hline & 0 & $-0.67(0.49)$ & $-0.67(0.49)$ & $-0.93(0.42) * *$ & $-1.27(0.47)^{* * * *}$ & $-1.26(0.46)^{* * * *}$ & $-1.01(0.40)^{* *}$ & $-1.03(0.83)$ \\
\hline \begin{tabular}{|l|} 
observations \\
\end{tabular} & & 523 & 523 & 588 & 383 & 383 & 398 & 393 \\
\hline Arellano-Bond AR(2) test p-value & & 0.348 & 0.337 & & 0.688 & 0.633 & 0.445 & 0.529 \\
\hline \multirow[t]{2}{*}{ Dep. Var. : $\Delta$ Real estate appreciation } & \multirow{3}{*}{ lag } & (8) & (9) & (10) & (11) & (12) & (13) & (14) \\
\hline & & High Financial Openness & Low Financial Openness & Euro Area Countries & Non Euro Countries & OECD Countries & Non OECD Episodes & Whole Sample \\
\hline Regressors & & \begin{tabular}{|l|} 
coefficient (std. err.) \\
\end{tabular} & coefficient (std. err.) & coefficient (std. err.) & coefficient (std. err.) & coefficient (std. err.) & coefficient (std. err.) & coefficient (std. err.) \\
\hline$\Delta$ Real estate valuation appreciation & 1 & $0.60(0.02)^{* * * *}$ & $0.72(0.04)^{* * * *}$ & $0.66(0.02)^{* * * *}$ & $0.63(0.03)^{* * * *}$ & $0.66(0.02)^{* * * *}$ & $0.61(0.04)^{* * * *}$ & $0.64(0.02)^{* * *}$ \\
\hline & 2 & $0.64(0.05)^{* * * *}$ & $0.64(0.08)^{* * *}$ & $0.80(0.06)^{* * *}$ & $0.61(0.05)^{* * *}$ & $0.76(0.05)^{* * * *}$ & $0.51(0.07)^{* * * *}$ & $0.64(0.04)^{* * *}$ \\
\hline & 3 & $-0.23(0.07)^{* * * *}$ & $-0.06(0.13)$ & $-0.34(0.09)^{* * *}$ & $-0.18(0.07)^{* *}$ & $-0.18(0.08)^{* *}$ & $-0.15(0.10)$ & $-0.19(0.06)^{* * * *}$ \\
\hline & 4 & $0.01(0.03)$ & $-0.06(0.07)$ & $0.10(0.05)^{* *}$ & $-0.01(0.04)$ & $-0.04(0.04)$ & $0.00(0.05)$ & $-0.00(0.03)$ \\
\hline Before Global financial crisis's Break & binary $(100)$ & $0.77(1.17)$ & $3.64(2.18)^{*}$ & $0.34(0.95)$ & $2.52(1.51)^{*}$ & $2.53(1.07)^{* * *}$ & $-2.08(2.49)$ & $1.71(1.05)$ \\
\hline$\Delta \mathrm{CAD} / \mathrm{GDP} \times$ Before Break & 1 & $0.79(0.75)$ & $0.61(1.05)$ & $-1.21(0.82)$ & $1.49(0.79)^{*}$ & $-0.00(0.81)$ & $1.55(1.03)$ & $0.83(0.67)$ \\
\hline & 2 & $0.91(0.69)$ & $3.22(1.11)^{* * * *}$ & $-0.22(0.78)$ & $1.26(0.74)^{*}$ & $0.62(0.74)$ & $1.79(0.99)^{*}$ & $1.52(0.61)^{* *}$ \\
\hline$\Delta \mathrm{CAD} / \mathrm{GDP} \times$ After Break & 1 & $0.63(0.65)$ & $0.28(0.93)$ & $-1.17(0.73)$ & $0.87(0.68)$ & $0.00(0.72)$ & $1.15(0.90)$ & $0.33(0.54)$ \\
\hline & 2 & $1.03(0.63)$ & $3.41(1.03)^{* * * *}$ & $-0.65(0.75)$ & $1.69(0.67)^{* *}$ & $0.42(0.69)$ & $2.27(0.91)^{* *}$ & $1.72(0.55)^{* * * *}$ \\
\hline$\Delta \mathrm{DCR} / \mathrm{GDP} \times$ Before Break & 1 & $0.61(0.27)^{* *}$ & $1.00(0.74)$ & $0.25(0.20)$ & $1.10(0.43)^{* * *}$ & $0.82(0.26)^{* * * *}$ & $-0.18(0.71)$ & $0.76(0.27)^{* * *}$ \\
\hline & 2 & $-0.15(0.18)$ & $-0.27(0.51)$ & $-0.28(0.13)^{* *}$ & $-0.12(0.29)$ & $-0.28(0.18)$ & $0.45(0.45)$ & $-0.15(0.18)$ \\
\hline$\triangle \mathrm{DCR} / \mathrm{GDP} \times$ After Break & 1 & $0.09(0.15)$ & $-0.18(0.48)$ & $0.03(0.11)$ & $0.05(0.24)$ & $0.05(0.15)$ & $0.13(0.33)$ & $0.12(0.15)$ \\
\hline & 2 & $0.14(0.11)$ & $-0.19(0.40)$ & $-0.04(0.08)$ & $0.32(0.19)^{*}$ & $0.10(0.11)$ & $0.06(0.27)$ & $0.11(0.11)$ \\
\hline$\Delta$ Equity market valuation appreciation & 1 & $0.19(0.04)^{* * * *}$ & $0.11(0.06)^{*}$ & $0.13(0.04)^{* * * *}$ & $0.17(0.04)^{* * * *}$ & $0.06(0.04)$ & $0.24(0.06)^{* * * *}$ & $0.16(0.03)^{* * * *}$ \\
\hline & 2 & $-0.13(0.07)^{*}$ & $-0.02(0.11)$ & $-0.14(0.07)^{*}$ & $-0.08(0.08)$ & $-0.03(0.07)$ & $-0.12(0.12)$ & $-0.10(0.06)$ \\
\hline & 3 & $0.06(0.06)$ & $-0.02(0.10)$ & $0.10(0.06)^{*}$ & $0.00(0.07)$ & $0.04(0.06)$ & $-0.02(0.10)$ & $0.03(0.05)$ \\
\hline & 4 & $-0.00(0.02)$ & $0.01(0.03)$ & $-0.01(0.02)$ & $0.01(0.02)$ & $-0.01(0.02)$ & $0.04(0.03)$ & $0.01(0.02)$ \\
\hline$\Delta$ CPI inflation & 1 & $-0.05(0.50)$ & $0.59(0.75)$ & $1.35(0.65)^{* *}$ & $-0.62(0.50)$ & $0.36(0.59)$ & $-0.90(0.65)$ & $-0.45(0.41)$ \\
\hline$\Delta$ Growth of industrial production & 1 & $0.12(0.10)$ & $-0.57(0.17)^{* * *}$ & $0.03(0.11)$ & $-0.13(0.11)$ & $0.27(0.11)^{* *}$ & $-0.34(0.14)^{* *}$ & $-0.06(0.09)$ \\
\hline$\Delta$ TED spread & 1 & $1.84(1.71)$ & $-5.14(3.69)$ & $1.03(1.50)$ & $-0.05(2.31)$ & $1.40(1.60)$ & $-2.01(3.72)$ & \\
\hline$\Delta \mathrm{VIX}$ & 1 & $-0.04(0.09)$ & $0.17(0.18)$ & $-0.02(0.08)$ & $-0.01(0.11)$ & $0.03(0.08)$ & $-0.04(0.17)$ & $0.01(0.05)$ \\
\hline$\Delta$ Sovereign CDS & 1 & $-0.06(0.20)$ & $-2.44(1.82)$ & $-0.10(0.12)$ & $-0.84(1.16)$ & $-0.07(0.18)$ & $-1.52(1.60)$ & $-0.12(0.21)$ \\
\hline Foreign reserve accumulation & 1 & $0.14(0.06)^{* *}$ & $-0.09(0.10)$ & $-0.13(0.37)$ & $0.04(0.06)$ & $0.06(0.06)$ & $0.03(0.09)$ & $0.05(0.05)$ \\
\hline Growth of Mortgage Origination in USA & 1 & & & & & & & $0.00(0.00)$ \\
\hline constant & 0 & $-1.03(0.51)^{* *}$ & $-0.80(1.01)$ & $-1.19(0.51)^{* *}$ & $-0.86(0.64)$ & $-1.25(0.48)^{* * * *}$ & $-0.19(1.08)$ & $-0.99(0.47)^{* *}$ \\
\hline observations & & 613 & 178 & 268 & 523 & 572 & 219 & 791 \\
\hline Arellano-Bond AR(2) test p-value & & 0.589 & 0.056 & 0.674 & 0.459 & 0.961 & 0.465 & 0.348 \\
\hline
\end{tabular}




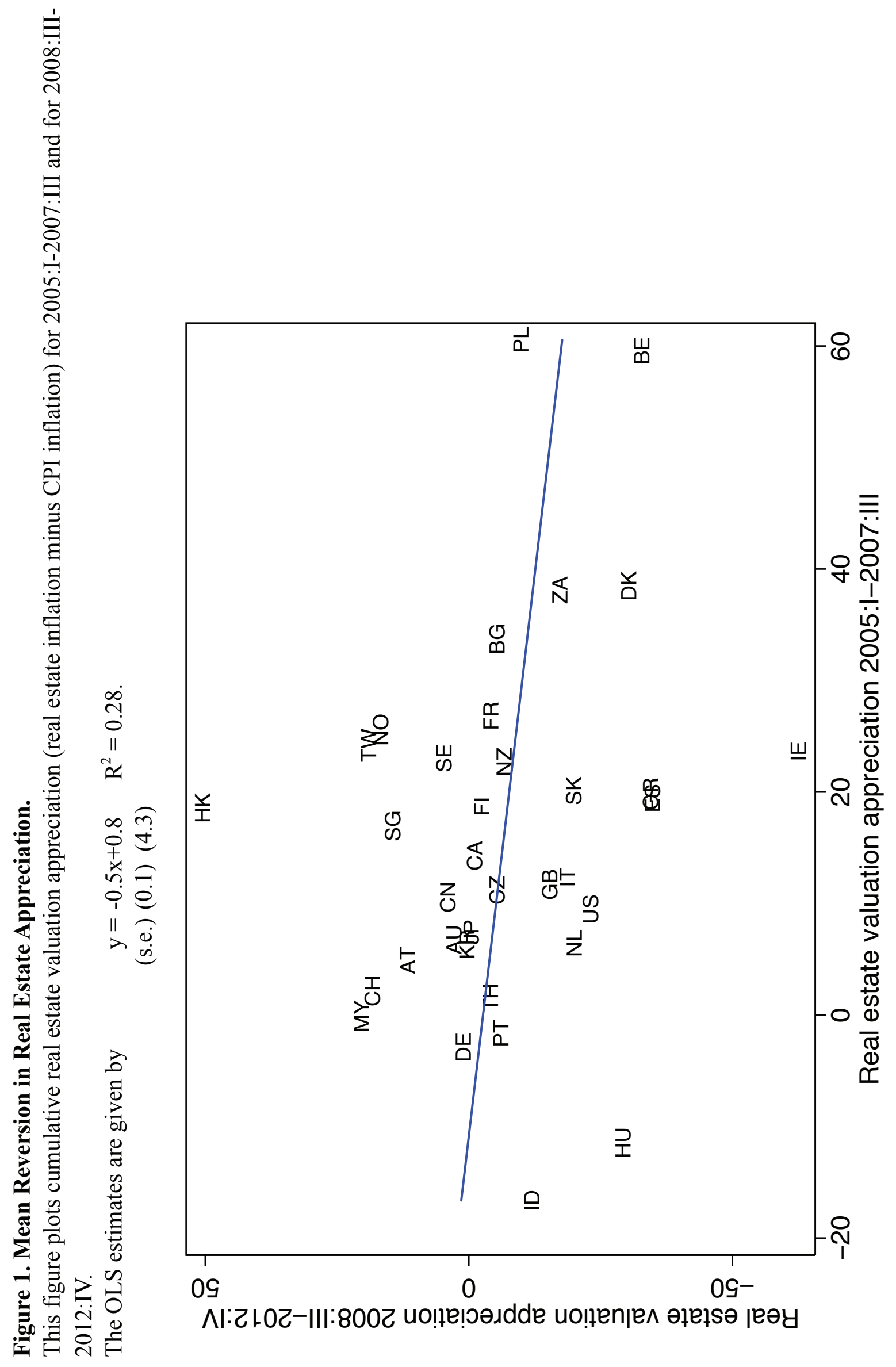



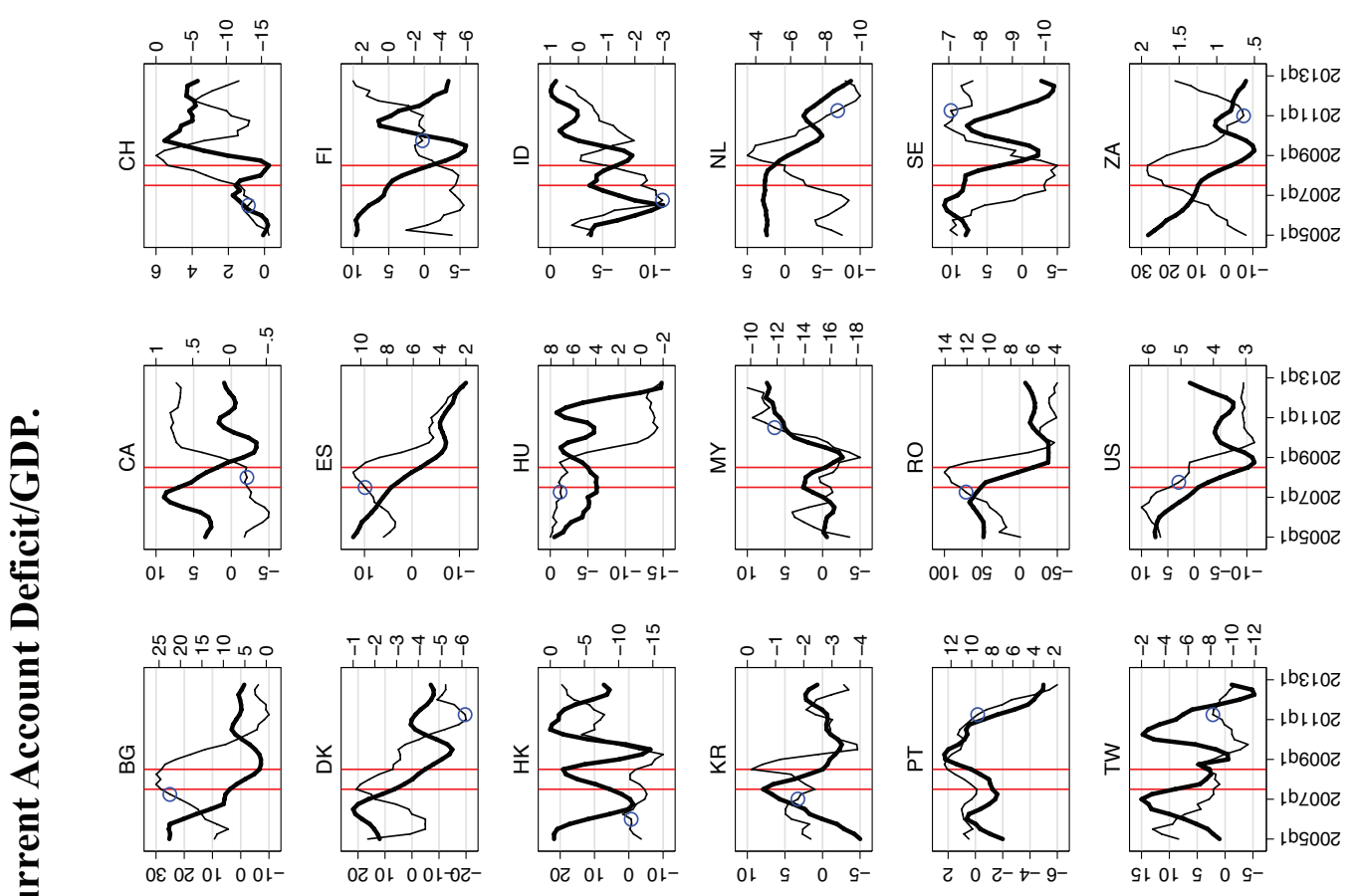

$\frac{2}{2}$

官

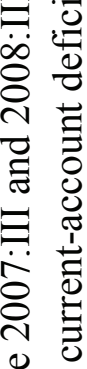

웅

क्ष

吼

푸

:

0

$3 \sim$

를

过

$\stackrel{5}{0}$
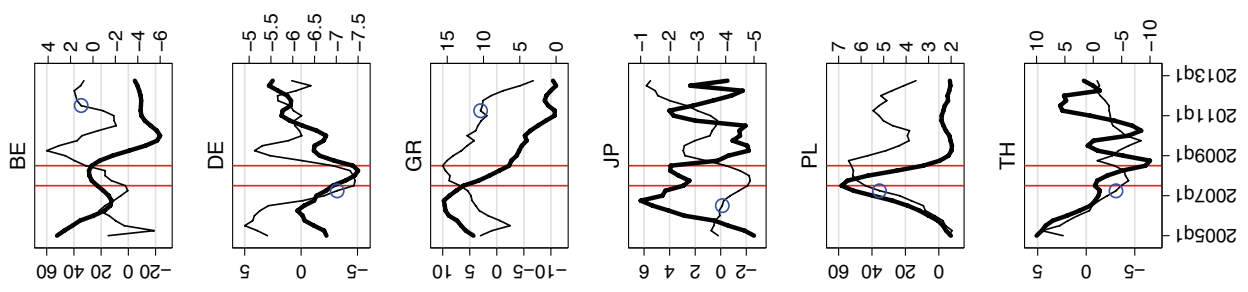

09 Ot $02 \quad 0$
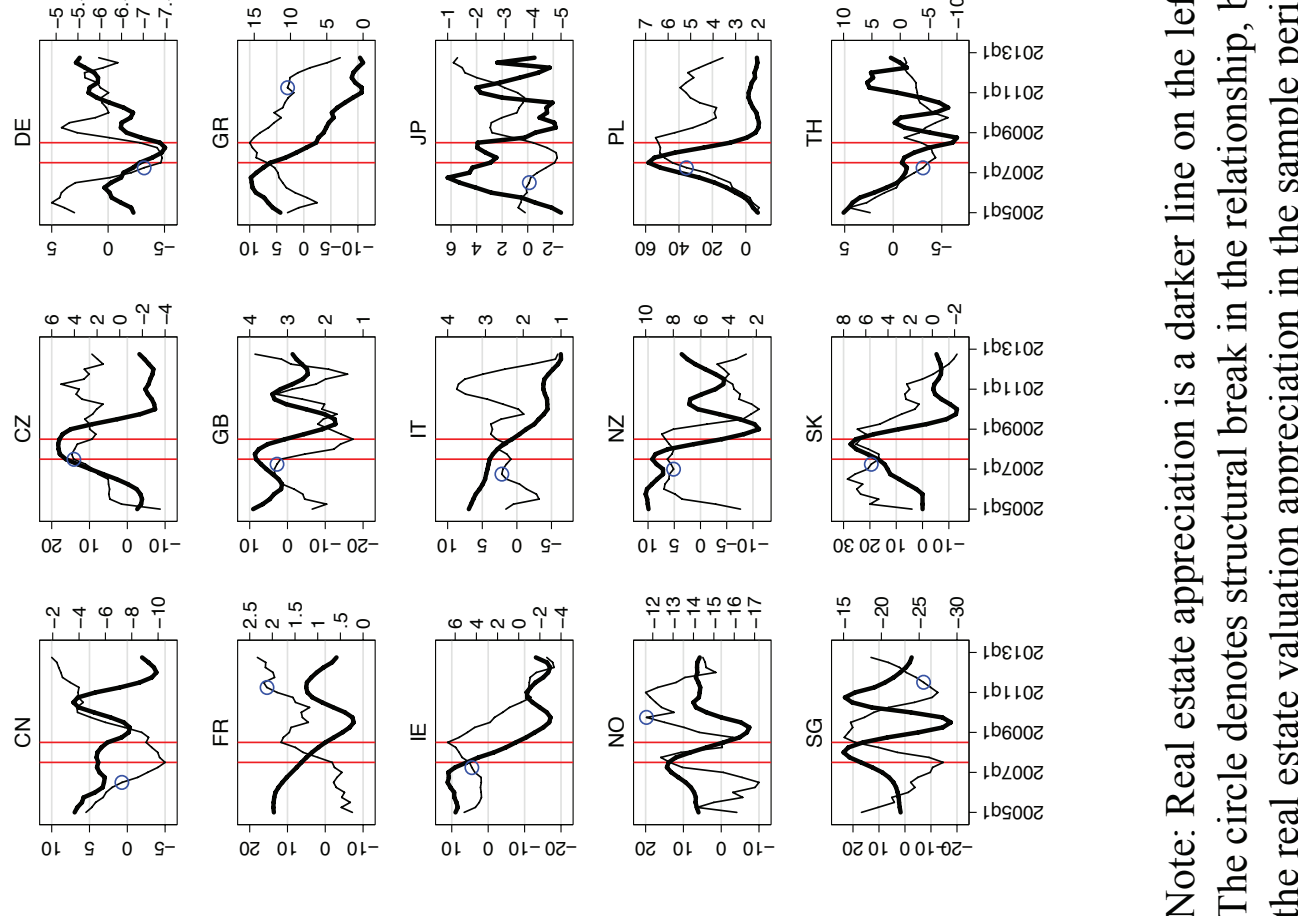

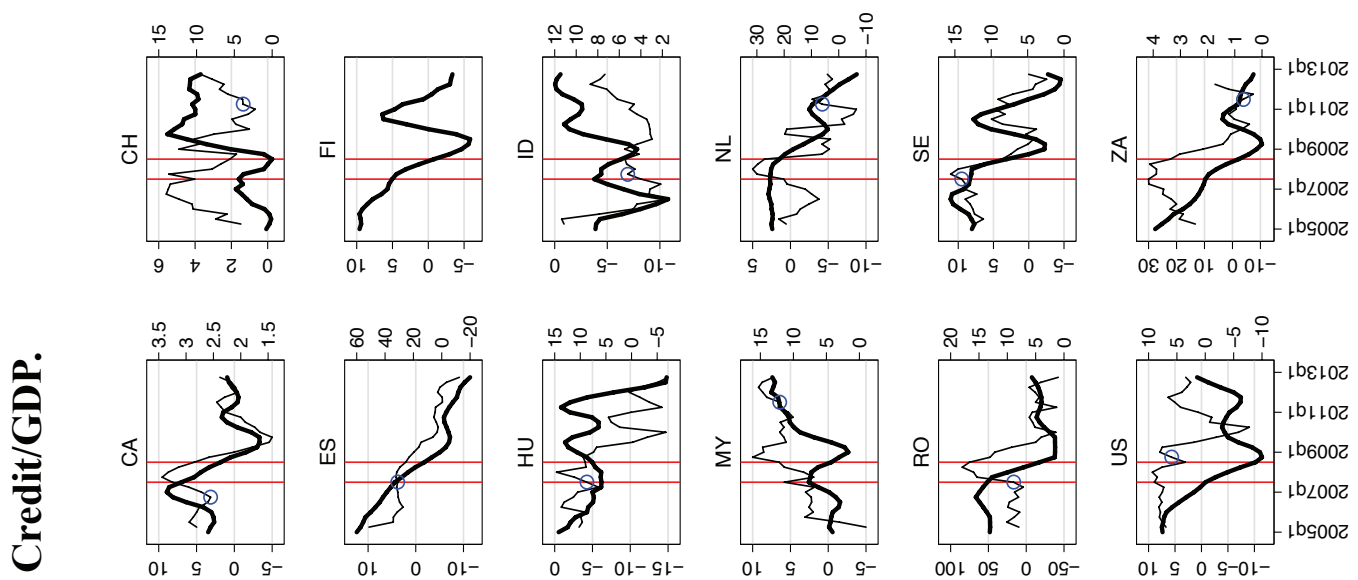

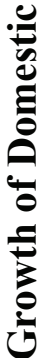
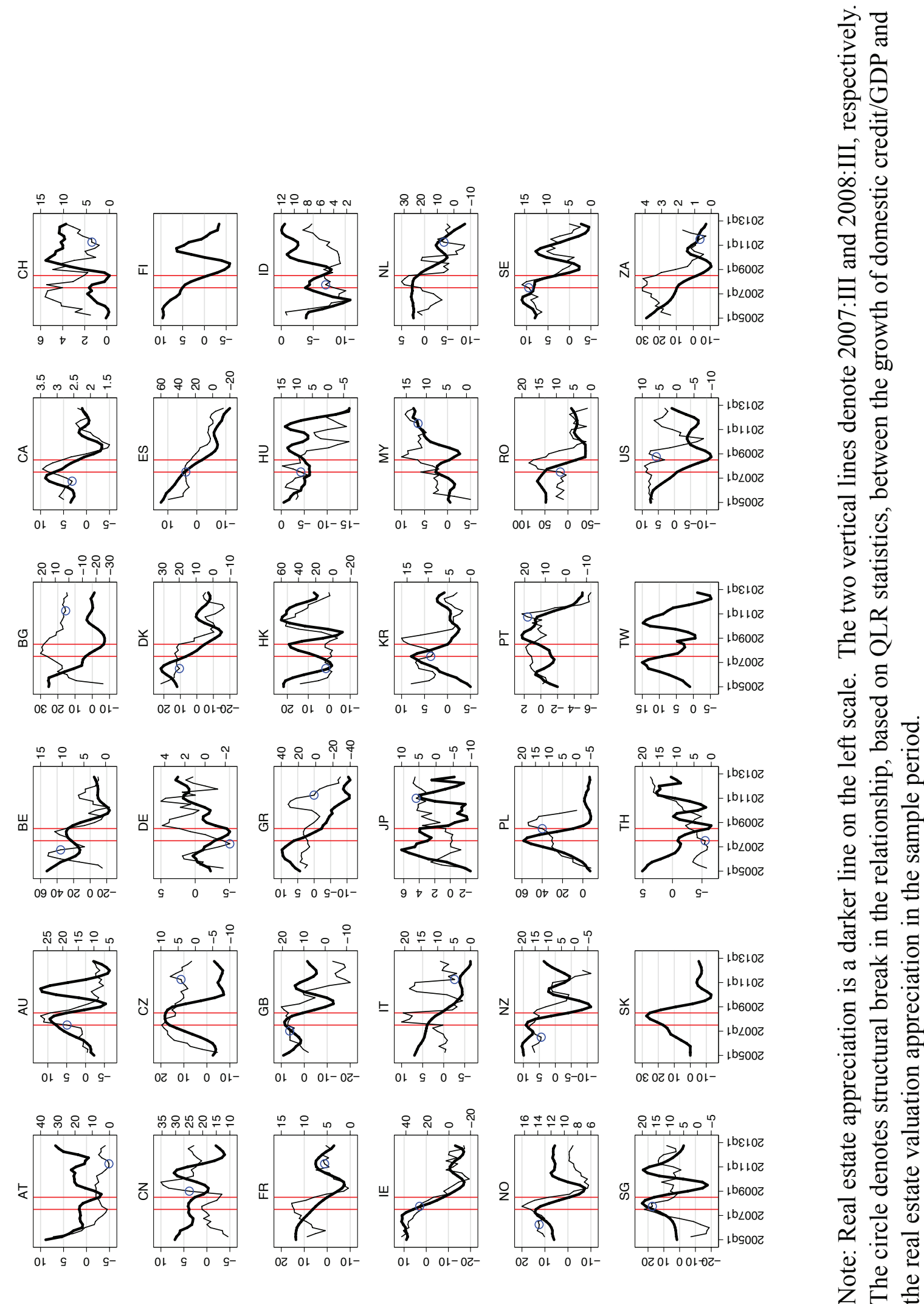


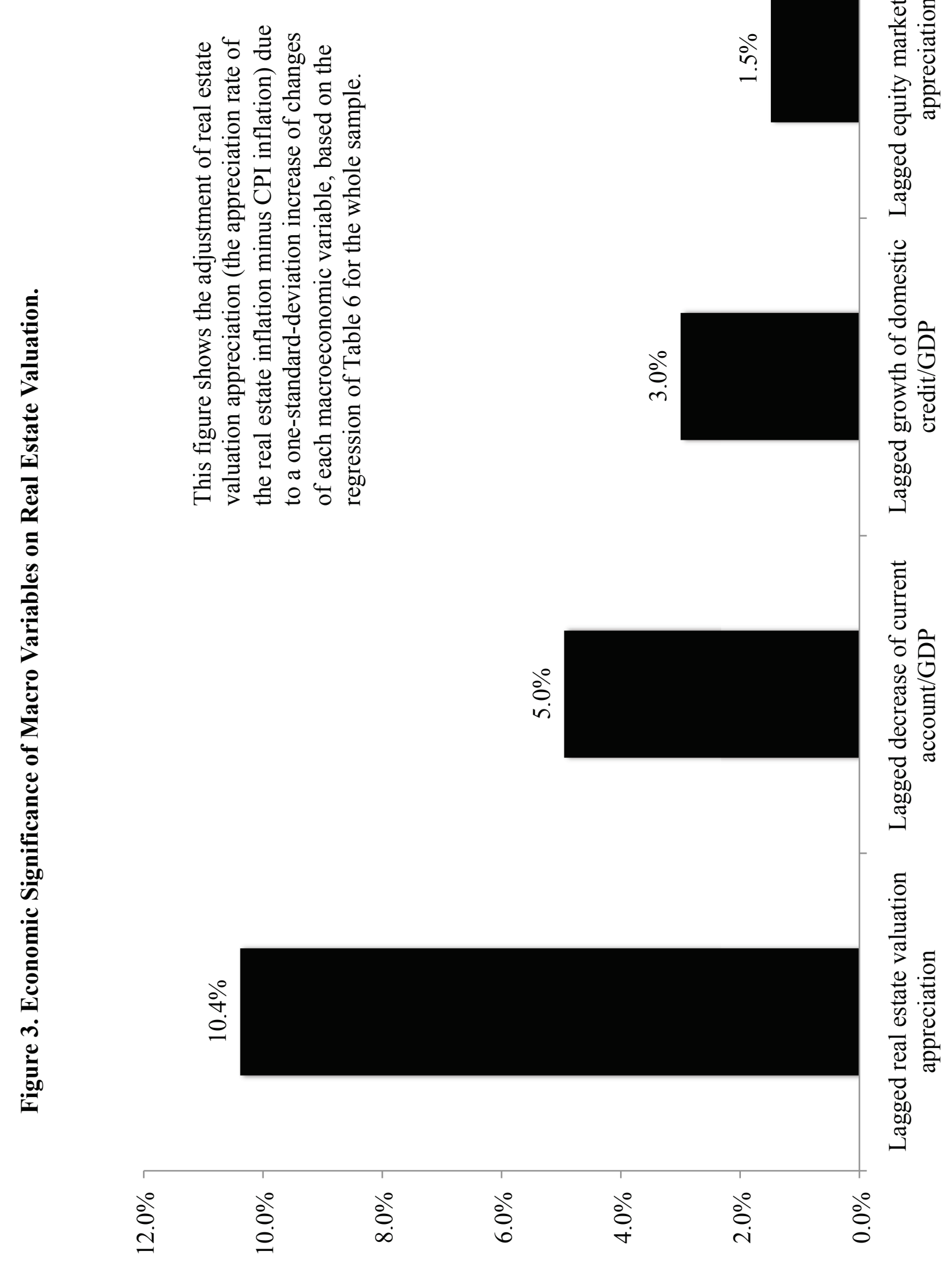

